\title{
Atmospheric impact of nitrous oxide uptake by boreal forest soils can be comparable to that of methane uptake
}

\author{
Henri M.P. Siljanen • Nina Welti 1 - Carolina Voigt • \\ Juha Heiskanen • Christina Biasi • Pertti J. \\ Martikainen
}

Received: 29 July 2019 / Accepted: 6 July 2020 /Published online: 23 July 2020

(C) The Author(s) 2020

\begin{abstract}
Aims Environmental factors controlling nitrous oxide $\left(\mathrm{N}_{2} \mathrm{O}\right)$ uptake in forest soils are poorly known, and the atmospheric impact of the forest $\mathrm{N}_{2} \mathrm{O}$ sink is not well constrained compared to that of methane $\left(\mathrm{CH}_{4}\right)$.

Methods We compared nitrous oxide $\left(\mathrm{N}_{2} \mathrm{O}\right)$ and $\mathrm{CH}_{4}$ fluxes over two growing seasons in boreal forest soils located in Eastern Finland. Within a spruce forest, we compared plots with long-term nitrogen $(\mathrm{N})$ fertilization history and non-fertilized plots, and additionally pine
\end{abstract}

Responsible Editor: Elizabeth M Baggs.

Electronic supplementary material The online version of this article (https://doi.org/10.1007/s11104-020-04638-6) contains supplementary material, which is available to authorized users.

H. M. Siljanen · N. Welti $(\bowtie) \cdot$ C. Voigt $\cdot$ C. Biasi •

P. J. Martikainen

Department of Environmental and Biological sciences, University of Eastern Finland, Yliopistonranta 1, 70210 Kuopio, Finland

e-mail: nina.welti@csiro.au

J. Heiskanen

Natural Resources Institute Finland, Neulaniementie 5,

FI-70210 Kuopio, Finland

Present Address:

N. Welti

Commonwealth Scientific and Industrial Research Organization, Agriculture and Food, Glen Osmond, Australia

Present Address:

C. Voigt

Department of Geography, University of Montreal, 1375 Avenue

Thérèse-Lavoie-Roux, Montreal, QC H2V 0B3, Canada forest plots without a fertilization history. The flux data was complemented with measurements of climatic conditions and soil physical and chemical characteristics, in order to identify factors affecting $\mathrm{N}_{2} \mathrm{O}$ and $\mathrm{CH}_{4}$ fluxes. Results Non-fertilized spruce forest soils showed the highest cumulative $\mathrm{N}_{2} \mathrm{O}$ uptake among the sites, whereas the pine forest site displayed low cumulative $\mathrm{N}_{2} \mathrm{O}$ emission. Nitrous oxide uptake was favored by high soil silt and water content. The low temperature seasons, spring and autumn, had the highest $\mathrm{N}_{2} \mathrm{O}$ uptake, likely associated with high soil water content typical for these seasons. In the spruce forest the $\mathrm{N}_{2} \mathrm{O}$ uptake was seasonally decoupled from the $\mathrm{CH}_{4}$ uptake.

Conclusions Applying the Global Warming Potential (GWP) approach, the cooling effect of $\mathrm{N}_{2} \mathrm{O}$ uptake in the spruce forest was on average $35 \%$ of that of $\mathrm{CH}_{4}$ uptake showing that $\mathrm{N}_{2} \mathrm{O}$ uptake should be considered when evaluating the atmospheric impact of boreal forests.

Keywords Nitrous oxide $\cdot$ Methane $\cdot$ Atmospheric uptake $\cdot$ Greenhouse gas $\cdot$ Denitrification

\section{Introduction}

The concentration of nitrous oxide $\left(\mathrm{N}_{2} \mathrm{O}\right)$ in the atmosphere has increased from $270 \mathrm{ppb}$ in preindustrial times to $328 \mathrm{ppb}$ today (Blasing 2017). This increase is mainly due to agricultural $\mathrm{N}_{2} \mathrm{O}$ emissions, but also resulting from wastewater treatment and fossil fuel burning (Machida et al. 1995; Flückiger et al. 1999; MacFarling Meure et al. 2006; Thomson et al. 2012; 
Blasing 2017). Nitrous oxide is a strong greenhouse gas which has a 298 times higher global warming potential than $\mathrm{CO}_{2}$ (based on a 100-yr time horizon; Myhre et al. 2014). Nitrous oxide also participates in reactions destroying ozone in the stratosphere. The contribution of $\mathrm{N}_{2} \mathrm{O}$ to global warming accounts for $6 \%$ of all greenhouse gases (Myhre et al. 2014). Due to the steady increase in the atmospheric $\mathrm{N}_{2} \mathrm{O}$ concentration the relative increase in global warming caused by $\mathrm{N}_{2} \mathrm{O}$ has been the second largest after $\mathrm{CO}_{2}$ during the last two decades (Hofmann et al. 2006; Forster et al. 2007).

Soils, particularly agricultural soil but also natural soils from the Tropics, represent $56-70 \%$ of the largest global source of $\mathrm{N}_{2} \mathrm{O}$ (Butterbach-Bahl et al. 2013; Syakila and Kroaze, 2011). In terrestrial ecosystems, $\mathrm{N}_{2} \mathrm{O}$ is produced in several microbiological $\mathrm{N}$ cycling processes such as chemolithotrophic ammonium $\left(\mathrm{NH}_{4}{ }^{+}\right)$oxidation (Wrage et al. 2005), denitrification (Braker and Conrad 2011), nitrifier denitrification (Kool et al. 2011), codenitrification (Spott et al. 2011), dissimilatory nitrate reduction (DNRA) (Laughlin and Stevens 2002), heterotrophic nitrification (Zhang et al. 2015) and chemodenitrification (van Cleemput and Samater 1995). Denitrification and nitrification are considered to be the most important processes for $\mathrm{N}_{2} \mathrm{O}$ production, with other processes contributing less than $1 \%$ to the total $\mathrm{N}_{2} \mathrm{O}$ emissions (Chapuis-Lardy et al. 2007).

The factors that regulate denitrification and nitrification in soils have been categorized as proximal and distal controls (Groffman et al. 1988). The key proximal factors directly controlling the reduction pathway in denitrification are soil oxygen $\left(\mathrm{O}_{2}\right)$ and nitrate $\left(\mathrm{NO}_{3}{ }^{-}\right)$ concentrations, availability of energy (organic compounds) and temperature (Tiedje 1987; ButterbachBahl et al. 2013). For chemolithotrophic nitrification availability of $\mathrm{O}_{2}, \mathrm{NH}_{4}{ }^{+}$and temperature are important proximal controls (Robertson 1989; Kowalchuk and Stephen 2001). Distal factors such as plants, management practices, soil texture and water availability indirectly regulate denitrification and nitrification activities by affecting the proximal controls (Tiedje 1987; Groffman et al. 1988; Wallenstein et al. 2006).

Soils can act as a source or sink for $\mathrm{N}_{2} \mathrm{O}$ (ChapuisLardy et al. 2007; Schlesinger 2013). Though the importance of soils as $\mathrm{N}_{2} \mathrm{O}$ sinks is considered to be small at a global scale, $\mathrm{N}_{2} \mathrm{O}$ uptake may be important regionally, e.g. in the boreal region, since most of the uptake seems to take place at high latitudes (Syakila and Kroeze 2011, Stewart et al. 2012; Brummell et al. 2014).
Denitrification is the most important microbial process known to consume $\mathrm{N}_{2} \mathrm{O}$. In denitrification, $\mathrm{NO}_{3}{ }^{-}$is reduced stepwise over several intermediates to $\mathrm{N}_{2} \mathrm{O}$, and finally to dinitrogen $\left(\mathrm{N}_{2}\right)$, the end product of denitrification. A key question is how efficiently the intermediate $\mathrm{N}_{2} \mathrm{O}$ is reduced to $\mathrm{N}_{2}$ and what factors regulate $\mathrm{N}_{2} \mathrm{O}$ reduction. Nitrous oxide is reduced to $\mathrm{N}_{2}$ by nitrous oxide reductase $\left(\mathrm{N}_{2} \mathrm{OR}\right)$. High availability of $\mathrm{NO}_{3}{ }^{-}$, low $\mathrm{pH}$, and low soil water content (high $\mathrm{O}_{2}$ availability), are among the factors decreasing the $\mathrm{N}_{2} \mathrm{OR}$ activity and increasing the ratio of $\mathrm{N}_{2} \mathrm{O}$ to $\mathrm{N}_{2}$ $\left(\mathrm{N}_{2} \mathrm{O}+\mathrm{N}_{2}\right)$ in denitrification (Weier et al. 1993; Tate 1995; Thomas et al. 1994; Schneider et al. 2012). In contrast, low $\mathrm{NO}_{3}{ }^{-}$availability and high soil water content favour the $\mathrm{N}_{2} \mathrm{OR}$ activity over the previous reductive steps, which could lead to net $\mathrm{N}_{2} \mathrm{O}$ consumption (uptake of $\mathrm{N}_{2} \mathrm{O}$ from the atmosphere) (ChapuisLardy et al. 2007). In nitrifier denitrification, $\mathrm{N}_{2} \mathrm{O}$ can also be consumed by reduction of $\mathrm{N}_{2} \mathrm{O}$ to $\mathrm{N}_{2}$ (Zart and Bock 1998; Shrestha et al. 2002; Megonigal et al. 2004).

Nitrous oxide uptake has been observed both in wetland and upland soils (Ryden 1981; Arah et al. 1991; Chapuis-Lardy et al. 2007). Water saturated ecosystems such as peatlands regularly show atmospheric $\mathrm{N}_{2} \mathrm{O}$ uptake (Martikainen et al. 1993; Marushchak et al. 2011). Upland forest soils, even when well-aerated, can also act as a sink for atmospheric $\mathrm{N}_{2} \mathrm{O}$. Periodic $\mathrm{N}_{2} \mathrm{O}$ uptake has been observed during dry periods in temperate Norway spruce forests (Bowden et al. 1991; Klemedtsson et al. 1997; Butterbach-Bahl et al. 1998; Goldberg and Gebauer 2009), during spring and autumn in temperate Red pine (Bowden et al. 1990) and Scots pine forests (Butterbach-Bahl et al. 2002) and boreal pine dominated forest (Machakova et al. 2019), in deciduous forests (Dong et al. 1998; Goossens et al. 2001), as well as in Mediterranean pine (Rosenkranz et al. 2006) and oak forests (Shvaleva et al. 2015). According to the best of our knowledge, data on $\mathrm{N}_{2} \mathrm{O}$ uptake from boreal spruce forests, an important coniferous forest type in the boreal region, is currently lacking.

Boreal forests cover approximately $11 \%$ of the total land area in the world (Archibold 1995) and play an important role in the global $\mathrm{CO}_{2}$ and $\mathrm{CH}_{4}$ balance (Brumme et al. 2005). Boreal forest soils have low mineral $\mathrm{N}$ availability (Turkington et al. 1998) and the nitrification activity in these $\mathrm{N}$ limited boreal forest soils is low (Martikainen 1984; Priha and Smolander 1999; Priha et al. 1999). Therefore, $\mathrm{N}_{2} \mathrm{O}$ emissions in nonfertilized boreal coniferous forests with low atmospheric 
$\mathrm{N}$ deposition are generally low (Ambus and Robertson 2006; Pihlatie et al. 2007; Kanakidou et al. 2016). However, the capacity of these $\mathrm{N}$ limited soils to consume atmospheric $\mathrm{N}_{2} \mathrm{O}$ is currently not known. If we consider the known controls on $\mathrm{N}_{2} \mathrm{O}$ reduction, the conditions in boreal forest soils could both support and inhibit $\mathrm{N}_{2} \mathrm{O}$ reduction: the low soil $\mathrm{NO}_{3}{ }^{-}$availability limits the overall denitrification but supports reduction of $\mathrm{N}_{2} \mathrm{O}$ to $\mathrm{N}_{2}$ (Palmer et al. 2011). Low pH, however, which is typical in boreal coniferous soils (even below 4) and low soil temperature could inhibit the activity of $\mathrm{N}_{2} \mathrm{OR}$ and thus support $\mathrm{N}_{2} \mathrm{O}$ production.

Our aim was to study in situ $\mathrm{N}_{2} \mathrm{O}$ dynamics in boreal spruce and pine forests. The spruce and pine forest study sites had distinct soil characteristics, and were subjected to different management practices (fertilized and nonfertilized), allowing us to study how soil characteristics and $\mathrm{N}$ fertilization affect $\mathrm{N}_{2} \mathrm{O}$ dynamics. We also quantified the isotopic signature of $\mathrm{N}_{2} \mathrm{O}$ in soil profile gas concentrations to insights into further partition $\mathrm{N}_{2} \mathrm{O}$ and behaviour of boreal forest soils processes within the soil profile as previous work has demonstrated reduction of $\mathrm{N}_{2} \mathrm{O}$ to $\mathrm{N}_{2}$ results in an ${ }^{15} \mathrm{~N}$ enrichment in $\mathrm{N}_{2} \mathrm{O}$ (Vieten et al. 2007; Gil et al. 2017). Forest soils are known to be a major global sink for atmospheric methane (Dutaur and Verchot 2007; Kirschke et al. 2013; Yu et al. 2017).Oxygen availability in well-drained upland forest soils is generally high, supporting microbial (methanotrophs) methane oxidation in these soils. Therefore, along with $\mathrm{N}_{2} \mathrm{O}$ dynamics, we assessed $\mathrm{CH}_{4}$ dynamics and compared the relative atmospheric impact of this trace gases over the growing seasons.

We aimed to answer three main questions with this research: 1) which soil management practices and 2) environmental characteristics support the potential for $\mathrm{N}_{2} \mathrm{O}$ uptake, and 3) what is the atmospheric importance of $\mathrm{N}_{2} \mathrm{O}$ uptake compared to that of $\mathrm{CH}_{4}$ uptake. We hypothesized that there are three main controls driving the capacity of boreal forest soils to act as a sink or source for $\mathrm{N}_{2} \mathrm{O}$ : 1) soil texture; 2) soil moisture; and 3) availability of mineral $\mathrm{N}$ (ammonium and nitrate).

\section{Materials and methods}

Study sites

The studied spruce forest was located in Heinävesi $\left(62^{\circ} 41^{\prime} \mathrm{N}, 28^{\circ} 71^{\prime} \mathrm{E}\right)$, and the pine forest in Suonenjoki $\left(62^{\circ} 38.782^{\prime} \mathrm{N}, 27^{\circ} 01.406^{\prime} \mathrm{E}\right)$, Eastern Finland. The spruce site was established by the Finnish Forest Research Institute in the early 1960 s to study the long-term effects of fertilization on forest growth. The tree stand consists mainly of Norway spruce (Picea abies) mixed with Rowan (Sorbus sp.), and the understory vegetation is dominated by blueberry (Vaccinium angustifolium Ait.). Sphagnum sp. mosses dominate the ground layer in wetter areas, whereas dryer areas had only $V$. angustifolium. The soil has a sandy loam texture. Two sub-sites in the spruce forest were studied, which were laid out in a split-block random design: 1) control (non-fertilized) site (CS site), and 2) nitrogen-fertilized site (NS site), where N fertilizer was applied in 4-10year intervals. From 1958 to 1965 , ammonium sulphate was used as the $\mathrm{N}$ fertilizer and from 1972 onwards ammonium sulphate was replaced by ammonium nitrate with lime following the general changes in forest fertilization practices in Finland. The total amount of applied of $\mathrm{N}$ until the year 2009 was $714 \mathrm{~kg} \mathrm{ha}^{-1}$ (Saarsalmi et al. 2014).

The pine forest site (CP) has no fertilization history, consists exclusively of pine (Pinus sylvestris), the understory vegetation has a sparse coverage of lingonberry (Vaccinium vitis-idaea) and the ground layer is dominated by lichens (Cladonia rangiferina) with some Sphagnum sp. mosses. The pine forest soil has loamy sand texture (ISO 14688).

Both soils are classified as Orthic podzol according to FAO guidelines (IUSS Working Group WRB 2006). The soil horizons A, E (eluviated), B (alluvial) and C horizons were overlain by an organic layer ( $\mathrm{O}$ thickness 3-10 cm).

Site preparation

To measure $\mathrm{N}_{2} \mathrm{O}$ and $\mathrm{CH}_{4}$ flux rates, four replicate aluminum collars $(60 \mathrm{~cm} \times 60 \mathrm{~cm})$ were installed permanently for the gas flux measurements at each of the three sites (CS, NS, CP) in June 2012. The distance between collars was 10-20 m. Additionally, we inserted perforated PVC tubes covered with gas permeable nylon fabric (Pihlatie et al. 2007) into the soil at the CS and NS sites for taking soil gas samples. The tubes were installed horizontally into the $\mathrm{O}, \mathrm{A}, \mathrm{E}, \mathrm{B}$ and $\mathrm{C}$-horizons, at depths of $5 \mathrm{~cm}, 15 \mathrm{~cm}, 25 \mathrm{~cm}, 35 \mathrm{~cm}$ and $50 \mathrm{~cm}$, respectively (Fig. $3 b$ and $\mathrm{S} 2$ ). To measure soil $\mathrm{O}_{2}$ concentration, soil moisture, soil and air temperatures continuously (data were collected every $30 \mathrm{~min}$ from which 
daily means were calculated) a Campbell Scientific CR3000 data logger equipped with multiplexer was used in 2013 and 2014 at the CS site. Data was collected with following sensors: moisture sensor (CS-616 water content reflectometer, Campbell Scientific, Inc., Shepshed, UK), temperature sensor (107-L temperature probe, Campbell Scientific, Inc., Shepshed, UK) and $\mathrm{O}_{2}$ sensor (GS Oxygen Sensor KE-25, Figaro USA Inc., Illinois, USA). Sensors were installed and calibrated as described previously (Gil et al. 2017) and inserted by drilling them into the soil profiles in March 2013 when soil was frozen.

\section{Measurements of nitrous oxide and methane fluxes}

The gas tightness between the soil and the collars was ensured by fixing a polyethylene membrane outside of the collars extending from the collars to the surrounding forest floor. Sand was added on the membrane on the forest floor. The collars were not pushed into the soil to avoid breakdown of plant roots and disturbances in nutrient uptake by plants and release of root exudates, all important factors for the activity of soil microbes. The upper part of the collar had a groove filled with water to create an airtight seal between the opaque aluminum chamber $(60 \mathrm{~cm} \times 60 \mathrm{~cm} \times 10 \mathrm{~cm}$, volume $361)$ and the collar during gas sampling. Each chamber had a circular vent tube to prevent development of under pressure within the chamber headspace during sampling (Nykänen et al. 1995). The chambers were equipped with a fan to ensure mixing of chamber air.

Gas samples were withdrawn from the chambers at intervals of 5, 10, 20 and $40 \mathrm{~min}$ with polypropylene syringes (Terumo, equipped with three-way stopcocks) during the 40 min enclosure time. Gas samples were transferred into $\mathrm{N}_{2}$-flushed and pre-evacuated glass vials closed with rubber septa (Labco Exetainer) within $24 \mathrm{~h}$ following sampling. The gas fluxes were measured at regular intervals during the 2012 growing season at all sites (approx. Every 3 weeks) (in total 27 flux measurements in 2012). The measurement frequency was increased in the 2013 growing season (between 9th April and 28th October 2013) at the CS and NS spruce sites so that fluxes were measured at regular 1-3 week intervals (in total 69 flux measurements in 2013).

The spatial heterogeneity of $\mathrm{N}_{2} \mathrm{O}$ fluxes at the CS site was studied by a grid sampling approach. On 16th July 2013, the fluxes and soil $\mathrm{NO}_{3}{ }^{-}$content were measured once across the site over a $14 \times 22 \mathrm{~m}$ plot using 25 measurement points (Fig. S1). These fluxes were measured with a round stainless steel chamber (volume $15 \mathrm{dm}^{3}$ ). The open bottom part of the chambers was pushed into soil to a depth of 3-7 cm.

Gas samples were analyzed for $\mathrm{N}_{2} \mathrm{O}$ and $\mathrm{CH}_{4}$ with an Agilent gas chromatograph (GC) equipped with a Hayesep Q 80/100 mesh column (length $1.8 \mathrm{~m}$ ) and an electron capture detector (ECD) for $\mathrm{N}_{2} \mathrm{O}$ and a flame ionization detector (FID) for $\mathrm{CH}_{4}$ (Nykänen et al. 1995). The flux rates were calculated by linear regression between the gas concentration data and sampling time. A correlation coefficient $>0.60$ was used as a quality criterion to accept the flux. The minimum detectable flux was calculated based on the GC detection limit (signal variation of standards in GC caused by the method) corresponding to \pm 0.77 s.d. $0.41 \mathrm{mg} \mathrm{CH}_{4} \mathrm{~m}^{-2} \mathrm{~d}^{-1}$ for $\mathrm{CH}_{4}$ and \pm 20.76 s.d. $9.86 \mu \mathrm{g} \mathrm{N}_{2} \mathrm{O} \mathrm{m}^{-2} \mathrm{~d}^{-1}$ for $\mathrm{N}_{2} \mathrm{O}$ $(N=35)$. Fluxes under this detection limit were excluded from further analyses. In total, $20 \%$ of $\mathrm{CH}_{4}$ and $7 \%$ of $\mathrm{N}_{2} \mathrm{O}$ fluxes were excluded. The atmospheric impact of $\mathrm{N}_{2} \mathrm{O}$ and $\mathrm{CH}_{4}$ fluxes was compared in $\mathrm{CO}_{2}$-equivalents using the Global Warming Potential approach (GWP, 100 year-time-horizon). The calculation of $\mathrm{CO}_{2}$-equivalents used 34 and 298 times greater GWP for $\mathrm{CH}_{4}$ and $\mathrm{N}_{2} \mathrm{O}$, respectively (Myhre et al. 2013). Cumulative fluxes were calculated by first calculating daily fluxes from measured hourly fluxes (assuming no diurnal variation) and then linearly interpolating between the measured daily fluxes for each sampling period (time between two sampling days) and summing the fluxes over all sampling periods.

\section{Environmental variables and soil characteristics}

Air temperature and precipitation data was obtained from a permanent meteorological station of the Finnish Meteorological Institute in Heinävesi (2 km away from the study site). Soil temperatures at $0,5,10$, and $20 \mathrm{~cm}$ soil depth were measured next to each collar during gas sampling. Photosynthetically Active Radiation (PAR) above the chambers was measured with a PAR meter (LI-250A, Li-Cor, Lincoln, USA) during the gas flux measurements.

Three soil cores ( $0-30 \mathrm{~cm}$ depth) were collected once per month near each collar after gas flux measurements using a corer ( $35 \mathrm{~mm}$ in diameter). The collected profile consisted of an O, A, and E-horizon which were separated by solid color differences. Soil moisture and chemical characteristics were determined from the two top 
soil layers (organic O and A-horizon). After sampling, soil layers were put in plastic bags sealed tightly with plastic liners and stored at $+4{ }^{\circ} \mathrm{C}$ in Styrofoam box with ice packages until soil analyses were done. Before analyses, soils were homogenized and then sieved to remove roots and stones (mesh size $3 \mathrm{~mm}$ ).

Soil water content of the $\mathrm{O}$ and A-horizons was measured by drying samples over night at $+60{ }^{\circ} \mathrm{C}$ and + $105{ }^{\circ} \mathrm{C}$, respectively. Soil particle density was measured by boiling a soil-water suspension of homogenized soil in pycnometers of known volumes for $30 \mathrm{~min}$. Water-filled pore space was calculated based on volumetric soil water content, particle density and bulk density. Organic matter (OM) content was estimated by loss-of-ignition at $550{ }^{\circ} \mathrm{C}$ for $2 \mathrm{~h}$ (Marushchak et al. 2011).

Two grams of field-moist soil were extracted with $15 \mathrm{ml}$ of $1.0 \mathrm{M} \mathrm{KCl}$ in sterile $50 \mathrm{ml}$ polypropylene tubes for determining $\mathrm{NO}_{3}{ }^{-}$and $\mathrm{NH}_{4}{ }^{+}$concentrations. The soil-KCl suspension was shaken for $60 \mathrm{~min}$ at $150 \mathrm{rpm}$ and subsequently centrifuged at $5000 \mathrm{rpm}$ for $10 \mathrm{~min}$. Extracts were filtered through $0.2 \mu \mathrm{m}$ sterile filters. Filtrates were then collected and frozen and refrigerated at $-80{ }^{\circ} \mathrm{C}$ until analysis. Soil $\mathrm{pH}$ and electrical conductivity were measured from soil-water suspension (1:2).

Nitrate concentrations were analyzed spectrophotometrically after reduction to nitrite. In brief, $\mathrm{NO}_{3}{ }^{-}$was reduced to nitrite with vanadium reagent $\left(\mathrm{VCl}_{3}\right)$ (at $+37^{\circ} \mathrm{C}, 90 \mathrm{~min}$ ) and nitrite was then measured spectrophotometrically at $544 \mathrm{~nm}$ using a mixture of N- (1napthyl) ethylenedianminedihydrochloride (NED) and sulfanilamide (SA) (Miranda et al. 2001). Ammonium was determined spectrophotometrically $(630 \mathrm{~nm})$ with the sodiumphenate, - prusside and -hypochlorite method (Fawcett and Scott 1960; Voigt et al. 2017).

To measure soil water retention characteristics, intact soil cores (diameter $50 \mathrm{~mm}$ ) were sampled next to the study plots from A-horizons. Particle size distribution was measured from air-dried mineral soil using a series of sieves (20 to $0.002 \mathrm{~mm} ; n=3$ ). Dry bulk density was determined as the ratio of dry mass (dried at $105^{\circ} \mathrm{C}$ ) to saturated volume $(n=3)$. Particle density was estimated using the water pycnometer method (Heiskanen 1993). Volumetric water content (VWC) at decreasing matric potentials (i.e. desorption water retention characteristics) was measured with intact soil cores using a pressure plate apparatus (Soil moisture Equipment Corp., Santa Barbara, California, USA) and standard methods (Klute 1986; Heiskanen 1993): metal cylinders were filled with each soil sample, saturated, allowed to drain freely (to about $-0.3 \mathrm{kPa}$ ), and then exposed to successive matric potential down to $-1500 \mathrm{kPa}(n=3)$. Water content was reassessed gravimetrically at each matric potential.

Total porosity (TP) was estimated using:

$\mathrm{TP}=\mathrm{AFP}+\mathrm{WC}$,

where AFP is air-filled porosity and WC is water content in vol.\% (porespace including air and water in pores, vol.\%).

Air-filled porosity (AFP) was estimated using:

$\mathrm{AFP}=\mathrm{TP}-\mathrm{VWC}$.

where VWC is the volumetric water content at $-10 \mathrm{kPa}$.

Nitrous oxide concentration in soil, ${ }^{14} \mathrm{~N} /{ }^{15} \mathrm{~N}-\mathrm{N}_{2} \mathrm{O}$ isotopic ratios and soil abiotic characteristics

Nitrous oxide concentration in soil profiles of the CS and NS sites were measured from gas samples taken from soil horizons, as described above (Fig. S4). Soil gases were collected with syringes (sample volume $25 \mathrm{ml}$ ) biweekly during the growing season after soil gas flux measurements and the $\mathrm{N}_{2} \mathrm{O}$ concentration was analyzed as described above.

The $\delta^{15} \mathrm{~N}-\mathrm{N}_{2} \mathrm{O}$ values in $\mathrm{N}_{2} \mathrm{O}$ in the sites having frequent $\mathrm{N}_{2} \mathrm{O}$ uptake (CS and NS) from soil gas, chamber headspace air, and ambient air were determined for the CS and NS sites on 28th August 2013 and 3rd of October, respectively (Fig. S4). Gas samples of $120 \mathrm{ml}$ were taken with a $150 \mathrm{ml}$ polyethylene syringe from the air and from soil gas collectors, respectively, and immediately injected into pre-evacuated $120 \mathrm{ml}$ Wheaton vials ensuring pressure equilibration. The isotopic ratio of $\mathrm{N}_{2} \mathrm{O}$ were measured with Thermo Finnigan Delta $\mathrm{V}$ Plus isotope ratio mass spectrometer (IRMS) operated in continuous-flow mode, coupled with an online Finnigan pre-concentrator unit (Precon; Thermo Finnigan, Germany) and gas chromatograph (Trace GC; Thermo Finnigan, Bremen, Germany) with PoraPlot Q capillary column $(0.32 \times 25 \mathrm{~m})$. Due to high aldehyde concentration in the soil gases especially in the uppermost soil horizons, the mass spectrometer was equipped with a selective aldehyde trap (Waters Inc.) which was attached in front of the ascartite column. The elemental analyzer (EA; Flash EA 112, Thermo Finnigan, Bremen, Germany) connected to the IRMS was used to measure the $\mathrm{C}$ and $\mathrm{N}$ content (\%) and the $\mathrm{C}: \mathrm{N}$ ratio of the soils. 
The $\delta^{15} N$ values of $\mathrm{N}_{2} \mathrm{O}$ (reported in parts per thousand; in \%o) were computed from ${ }^{14} N /{ }^{15} N$ ratios using the following equation:

$\delta^{15} \mathrm{~N}-\mathrm{N}_{2} \mathrm{O}=($ Rsample/Rstandard -1$) \times 1000$.

Where $\mathrm{R}$ is the ${ }^{15} \mathrm{~N} /{ }^{14} \mathrm{~N}$ ratio of $\mathrm{N}_{2} \mathrm{O}$ and the standard is atmospheric $\mathrm{N}_{2}$. The precision of the isotopic composition measurements in $\mathrm{N}_{2} \mathrm{O}$ was better than $0.3 \%$ o.

\section{Statistical analyses}

All statistical tests were made with $\mathrm{R}$ statistical program version 3.2.2 ( $\mathrm{R}$ Core Team 2015). The data was separated into two subsets for statistical analyses to cover the three main hypotheses of the study: 1) to identify the overall controls on $\mathrm{N}_{2} \mathrm{O}$ fluxes in the CS, NS and CP sites sampled evenly in year 2012 (data used for testing hypotheses 1,2,3); and 2) to study the effect of past fertilization and availability of mineral $\mathrm{N}$ on $\mathrm{N}_{2} \mathrm{O}$ fluxes in the intensively sampled spruce sites (CS and NS) over multiple years (2012-2014) (data used for testing hypothesis 2).

Prior to statistical analyses, data were tested for normal distribution using histograms and density and qq-plots coupled with the Shapiro-Wilk normality test. The differences in the cumulative fluxes between forest types were tested with Two-Way ANOVA and TukeyHSD post hoc comparison. The spatial interpolation over the sampling plots at the CS site was calculated with R package geoR (Paulo et al. 2016).

To examine the strength of the factors regulating $\mathrm{N}_{2} \mathrm{O}$ flux, correlations between environmental variables and $\mathrm{N}_{2} \mathrm{O}$ fluxes were done with the nonparametric Spearman's correlation test. We applied principle component analysis (PCA) to reduce data dimensionality and to visualize the variance structure of dataset 1 , in order to identify differences between sites and treatments in terms of $\mathrm{N}_{2} \mathrm{O}$ fluxes, soil and environmental properties. The variables included in the PCA were scaled (standardized to unit variance). Six components were included in the PCA, and PCAbiplots were created using R-packages FactoMineR (Lê et al. 2008) and factoextra (Kassambara and Mundt 2016).

To account for the differences among sites (spruce vs. pine (dataset 1)) as well as treatment (fertilized vs. non-fertilized spruce (dataset 2)), and to account for repeated measurements on the same plot in multiple years, we applied linear mixed-effects models (Rpackage lme4, Bates et al. 2015), following the procedure described by Zuur et al. (2009) and Voigt et al. (2017).

We created two distinct statistical models: model 1 (dataset 1) included both forest types (sites CS and CP) for the evenly sampled 2012 dataset to evaluate which of the environmental factors were explaining variation in $\mathrm{N}_{2} \mathrm{O}$ fluxes, and model 2 (dataset 2) included data obtained from the spruce forest sites (CS and NS) (years 2012-2014), with fertilized and non-fertilized treatments (in total, 11 measured timepoints). The final output for model 1 was constructed using forest type (pine vs. spruce), treatment (fertilized vs. non-fertilized), soil layer (O or A-horizon), air temperature and $\mathrm{pH}$ in the fixed effects structure, and the interaction of sampling time and treatment as random effects. Model 2 included treatment, air temperature, $\mathrm{pH}$, WFPS, as well as the interactions of $\mathrm{NH}_{4}{ }^{+}$with air temperature and $\mathrm{pH}$ as fixed effects, and plot nested in sampling time as random effects.

\section{Results}

Soil physical and chemical properties

Spruce soil had sandy loam soil texture, whereas the pine soil had loamy sand texture (Table 1). Content of $\mathrm{OM}$ was highest in the O-horizon of the fertilized spruce forest soil. However, the effect of fertilization was not seen in the $\mathrm{C}: \mathrm{N}$ ratio of OM. In general, $\mathrm{NO}_{3}{ }^{-}$ concentration in the pine soil was lower than in the spruce soils, and the O-horizon of the fertilized spruce soil had the highest $\mathrm{NO}_{3}{ }^{-}$concentration. The same trend was noticeable for $\mathrm{NH}_{4}{ }^{+}$concentrations in $\mathrm{O}$ horizons, but generally $\mathrm{NH}_{4}{ }^{+}$concentrations were an order of magnitude lower than $\mathrm{NO}_{3}{ }^{-}$concentrations. Soil $\mathrm{pH}$ was lowest in the non-fertilized spruce soil (CS). Soil electrical conductivity was lowest in the pine soil (CP). We observed a trend towards higher water content and water-filled-pore-space (WFPS) in the spruce sites compared (CS and NS) to the pine site. Field capacity of the A horizon of the spruce forest (CS and NS) was higher than that of the pine forest A horizon. 


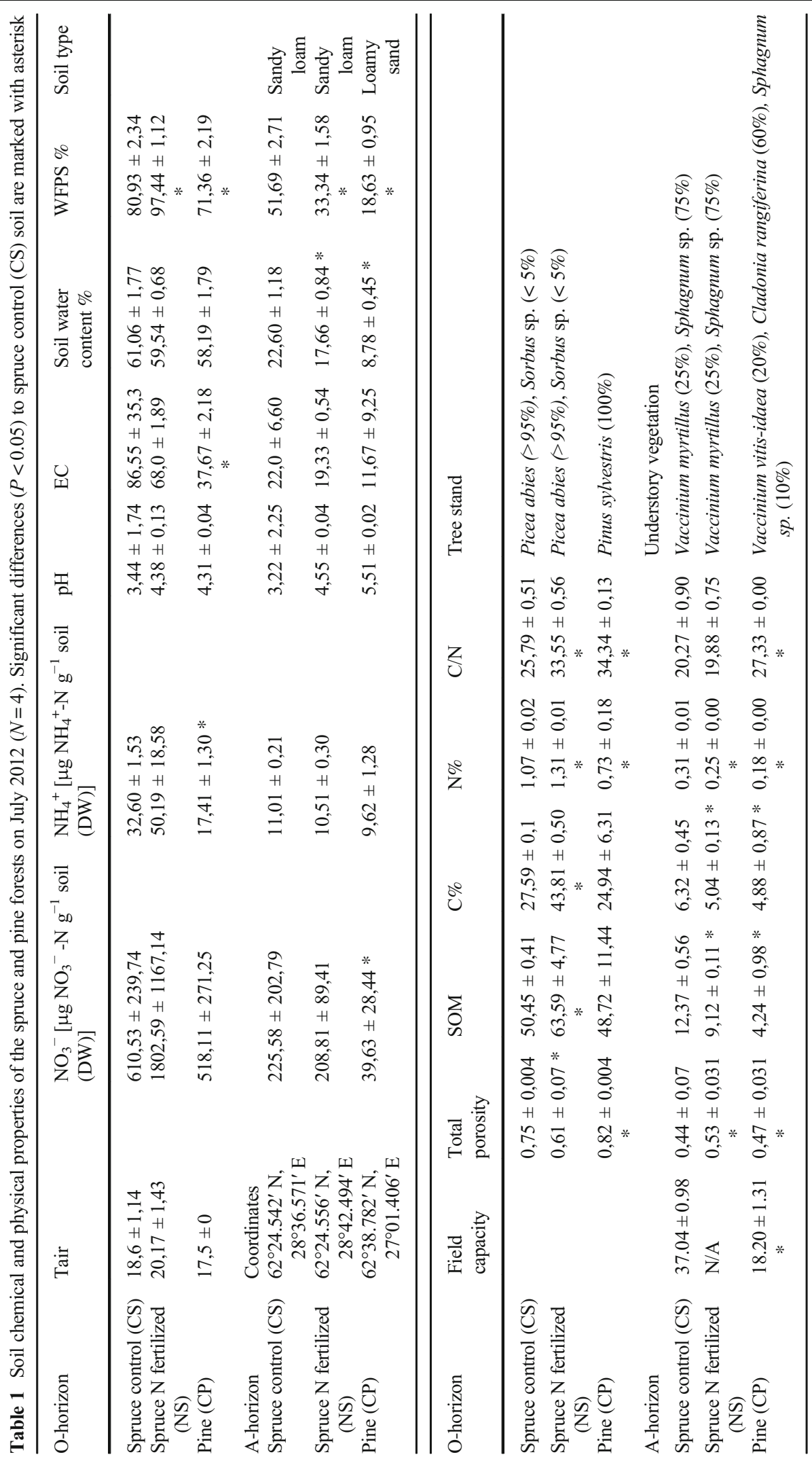


Nitrous oxide fluxes

Nitrous oxide fluxes in the spruce and pine sites

Nitrous oxide fluxes varied between uptake rates of $-631.7 \mu \mathrm{g} \mathrm{N} \mathrm{N}_{2} \mathrm{O} \mathrm{m}{ }^{-2} \mathrm{~d}^{-1}$ to emissions of $591.3 \mu \mathrm{g}$ $\mathrm{N}_{2} \mathrm{O} \mathrm{m}^{-2} \mathrm{~d}^{-1}$, and $\mathrm{CH}_{4}$ fluxes ranged between -10.8 and $4.2 \mathrm{mg} \mathrm{CH}_{4} \mathrm{~m}^{-2} \mathrm{~d}^{-1}$ across all study sites during the 2012 growing season. The cumulative $\mathrm{N}_{2} \mathrm{O}$ fluxes differed significantly between sites (Fig. 1a. $F^{\text {sites }}=7.325$; $P<0.05)$. In June-July 2012, the pine forest showed cumulative $\mathrm{N}_{2} \mathrm{O}$ emissions, whereas the spruce control site displayed cumulative $\mathrm{N}_{2} \mathrm{O}$ uptake (Fig. 1.), and the fluxes differed significantly from each other and from zero $(P<0.05)$. All sites showed cumulative $\mathrm{CH}_{4}$ uptake rates, which were highest at the $\mathrm{CS}$ site, and slightly (not significant) lower at the NS and P sites.

\section{Comparison of nitrous oxide uptake with methane uptake}

Methane and nitrous oxide showed a pronounced decoupling at the CS site in 2013 (Fig. 2a), i.e. $\mathrm{N}_{2} \mathrm{O}$ fluxes were larger during wet periods when $\mathrm{CH}_{4}$ fluxes were close to zero. On the other hand, during times of pronounced $\mathrm{CH}_{4}$ uptake the $\mathrm{N}_{2} \mathrm{O}$ fluxes were fluctuating around zero. The global warming potential (GWP) approach was used to compare the atmospheric impacts

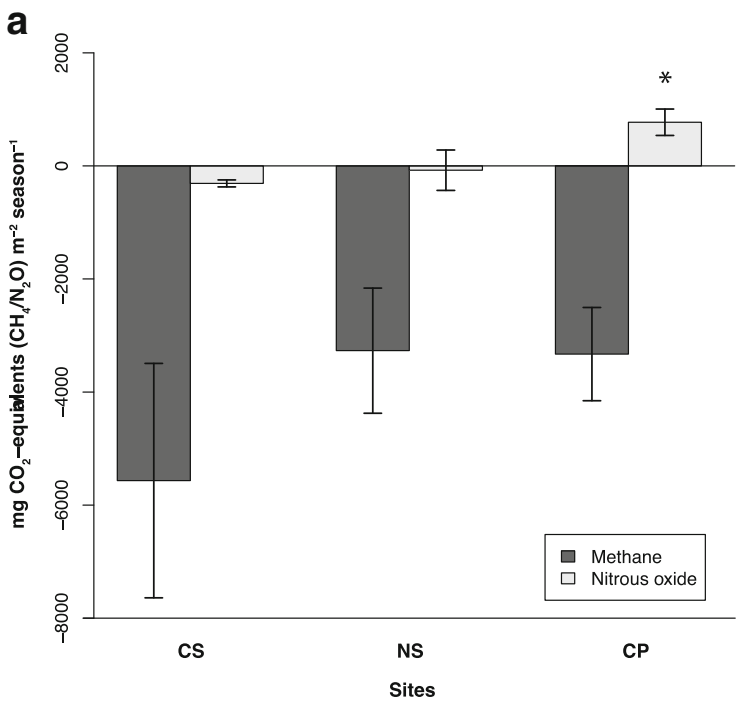

Fig. 1 a Cumulative $\mathrm{CH}_{4}$ and $\mathrm{N}_{2} \mathrm{O}$ fluxes shown as $\mathrm{CO}_{2}$-equivalents from boreal forests. Measurements were conducted during 12th June - 27th July in $2012(\mathrm{n}=4)$. Significant differences as compared to CS site are shown with asterisk $(\mathrm{P}<0.05)$. b of the cumulative $\mathrm{N}_{2} \mathrm{O}$ and $\mathrm{CH}_{4}$ uptake (Fig. 1b, calculated with data shown in Fig. 2a) in the CS site during growing season 2013. Expressed as $\mathrm{CO}_{2}$ - equivalents, the GWP of the $\mathrm{N}_{2} \mathrm{O}$ uptake was on average $35 \%$ of the $\mathrm{CH}_{4}$ uptake (Fig. 1b).

Seasonal and spatial variation of nitrous oxide fluxes

Nitrous oxide fluxes in the CS and NS sites varied from low emission to uptake in 2013 (Supplementary Fig. $\mathrm{S} 2$ ). At the $\mathrm{CS}$ site, $\mathrm{N}_{2} \mathrm{O}$ emissions were highest during the summer, whereas there was uptake in early spring, late autumn and winter. In contrast, $\mathrm{N}_{2} \mathrm{O}$ fluxes at the NS site were less variable over the seasons. However, despite the different seasonal patterns in $\mathrm{N}_{2} \mathrm{O}$ fluxes at the CS and NS sites, the mean fluxes at these sites did not differ significantly (Linear mixed effect model: Fig. S2, $P=0.334$ in Table S1). The interaction effect of $\mathrm{NH}_{4}{ }^{+}$concentration in A-horizon and soil $\mathrm{pH}$ on $\mathrm{N}_{2} \mathrm{O}$ fluxes in the spruce sites was the strongest and only significant factor explaining the variation $(P=0.045$ in Table S1., results of model 2 retrieved from dataset 2 ). The highest uptake occurred in April before snow melt (Fig. 2a), when soil was still frozen (Fig. 2c). During this peak $\mathrm{N}_{2} \mathrm{O}$ uptake in spring temperature was low, soil water content was high and there was a decrease in $\mathrm{O}_{2}$ concentrations in the soil profile (minimum $\mathrm{O}_{2}$ concentration about 10\%) (Fig. 2 b, c, d).

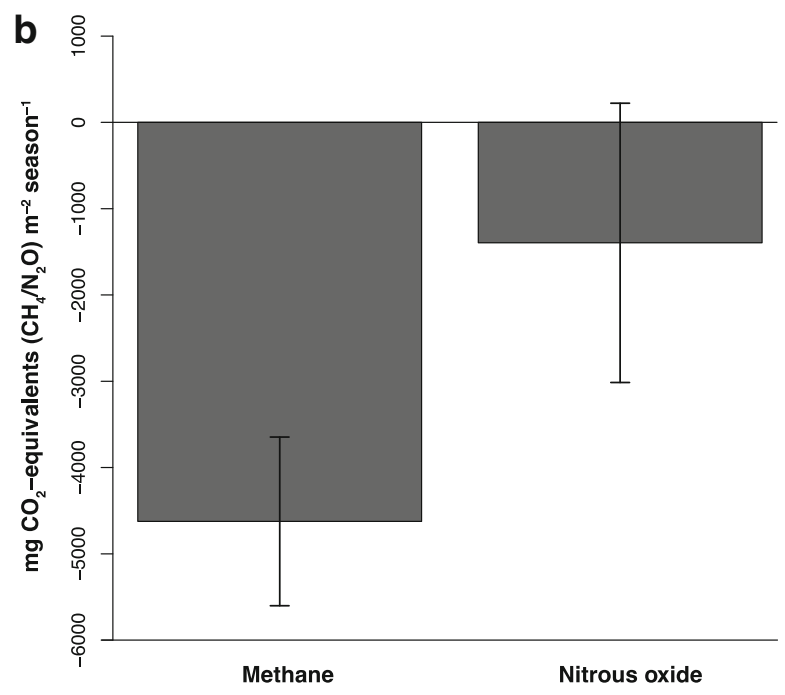

Comparison of cumulative $\mathrm{N}_{2} \mathrm{O}$ and $\mathrm{CH}_{4}$ fluxes as $\mathrm{CO}_{2}$ equivalents for the growing season in the CS sub-site. Measurements were done between 9th April and 3rd October in 2013 
a)

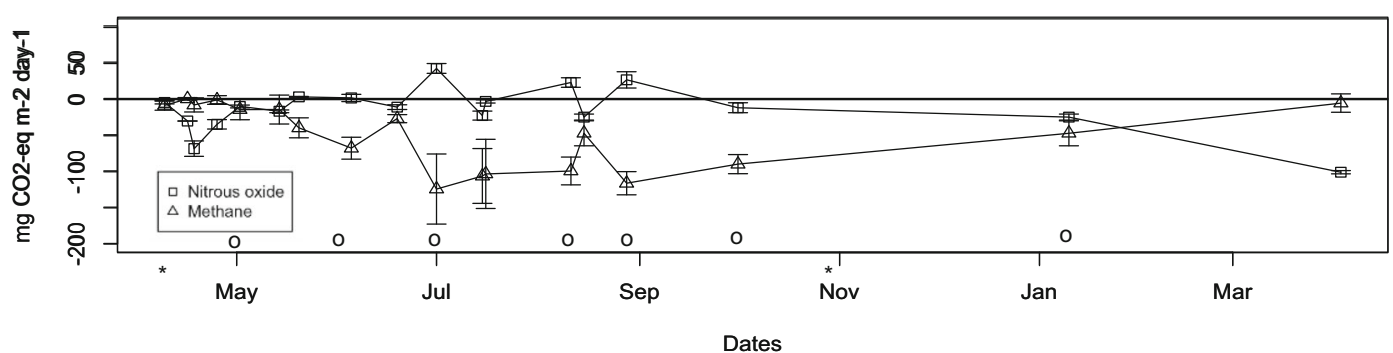

b)

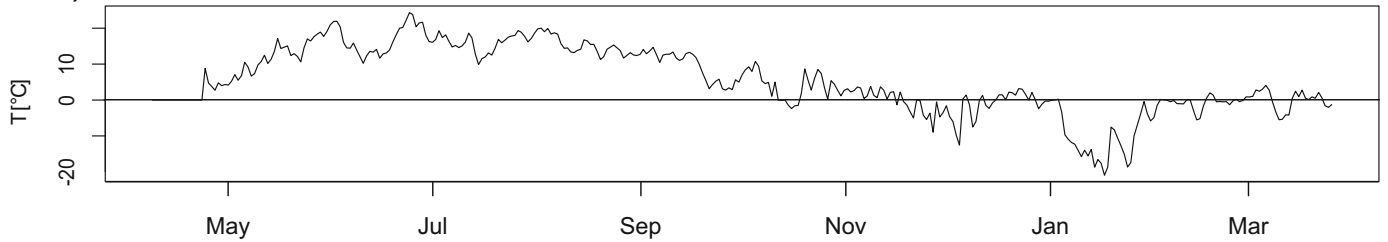

c)
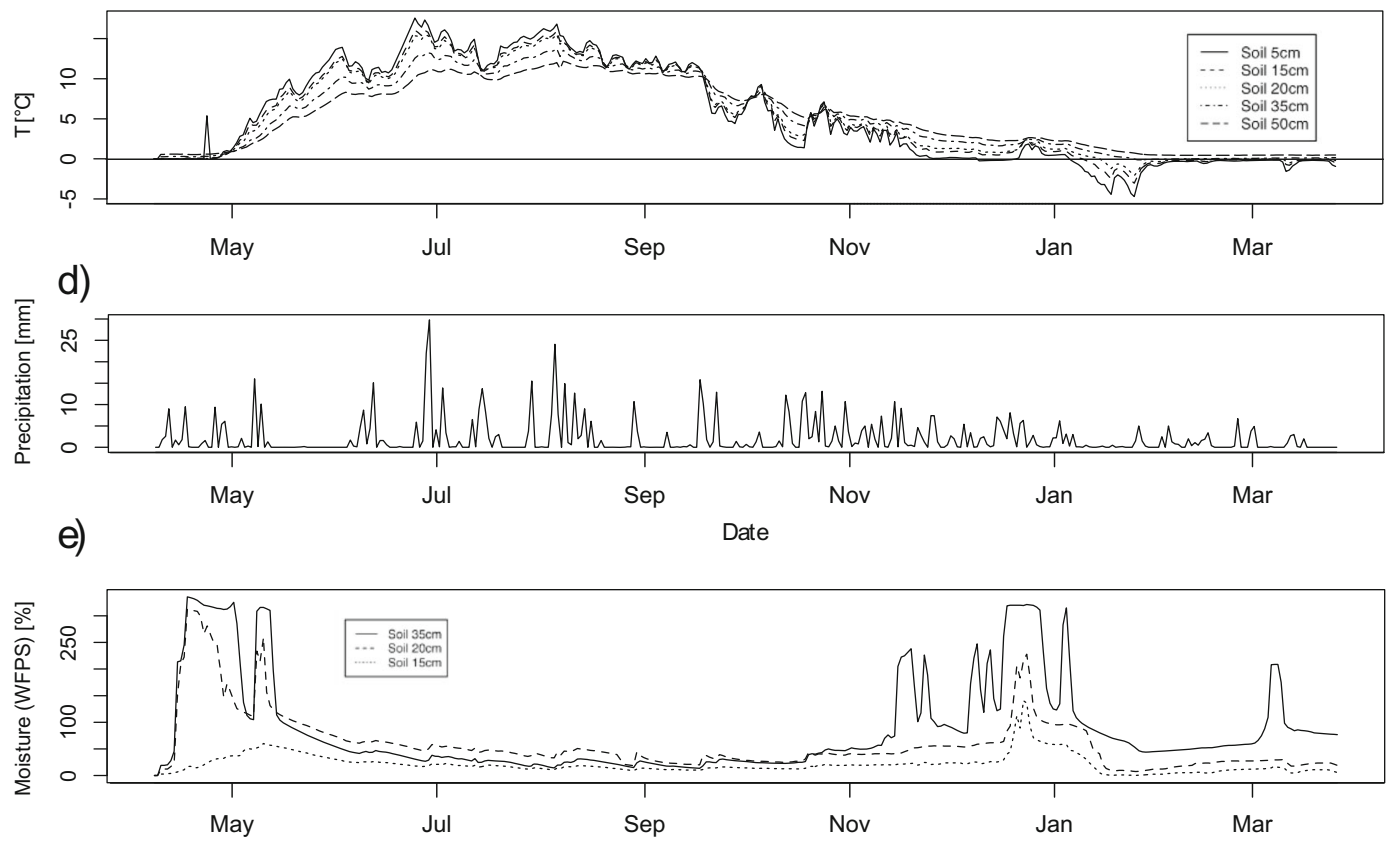

f)

Date

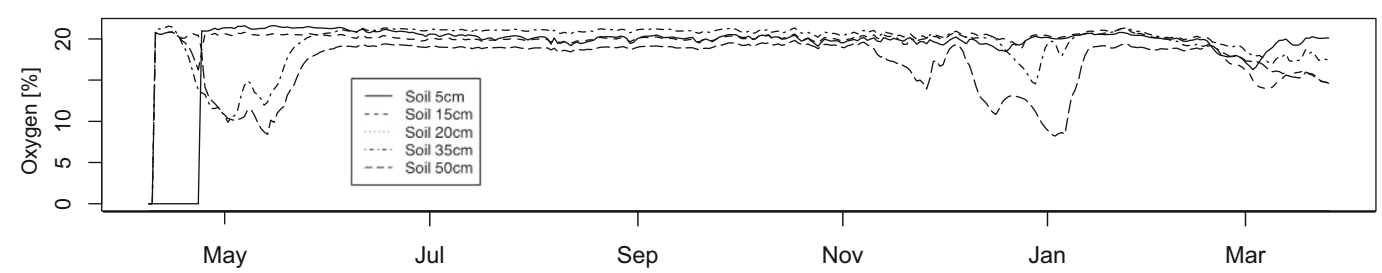

Month

Fig. $2 \mathrm{~N}_{2} \mathrm{O}$ and $\mathrm{CH}_{4}$ fluxes in 2013-2014 expressed as $\mathrm{CO}_{2}$ equivalents at the $\mathrm{CS}$ site (a) soil sampling points shown with ${ }^{\circ}$ mark, air temperature (b), soil profile temperatures (c), precipitation (d), soil moisture (e) and $\mathrm{O}_{2}$ concentration in soil profile (f). The beginning and the end of the growing season in 2013 (9th April and 28th October) is marked with asterisk in (a) 
Spatial variation of $\mathrm{N}_{2} \mathrm{O}$ fluxes was measured at the CS site with a grid sampling approach. While $\mathrm{N}_{2} \mathrm{O}$ fluxes at the CS site displayed spatial variation, the mean fluxes measured on the same day from 25 measurement points of a $5 \mathrm{~m} \times 15 \mathrm{~m}$ spatial sampling plot (Fig. 3a) and permanent collars both showed $\mathrm{N}_{2} \mathrm{O}$ uptake (-84.6 s.d. $33.1 \mu \mathrm{g} \mathrm{N}_{2} \mathrm{O} \mathrm{m}^{-2} \mathrm{~d}^{-1}$ and -181.64 s.d. $132.2 \mu \mathrm{g} \mathrm{N}_{2} \mathrm{O} \mathrm{m} \mathrm{m}^{-2}$, respectively).

The $\mathrm{N}_{2} \mathrm{O}$ fluxes were highly variable across the study site. Even though this approach was used only once, it highlights the spatial variability of $\mathrm{N}_{2} \mathrm{O}$ fluxes. The average fluxes obtained from the grid sampling measurements reflect the areal estimate of the overall $\mathrm{N}_{2} \mathrm{O}$ flux of the study site (mean $-84.62 \pm$ $33.13 \mu \mathrm{g} \mathrm{N}_{2} \mathrm{O} \mathrm{m}^{-2} \mathrm{~d}^{-1}$ ). The mean flux rate from the grid sampling approach was rather similar to the mean flux rate measured from permanent plots $(-132 \mu \mathrm{g}$ $\mathrm{N}_{2} \mathrm{O} \mathrm{m}^{-2} \mathrm{~d}^{-1}$ ) on the same day, located inside the grid sampling plot.

During the growing season, the $\mathrm{N}_{2} \mathrm{O}$ concentrations in CS soil profile increased with depth, being highest at a depth of $35 \mathrm{~cm}$. This was reflected by high $\mathrm{N}_{2} \mathrm{O}$ emissions (Fig. 3b). When $\mathrm{N}_{2} \mathrm{O}$ uptake was measured, $\mathrm{N}_{2} \mathrm{O}$ concentrations were below the ambient concentration in the uppermost soil horizons (Oand A-horizons) (Fig. 3b). $\delta^{15} \mathrm{~N}$ enrichment of $\mathrm{N}_{2} \mathrm{O}$ was present at $15 \mathrm{~cm}$ depth of the spruce forest (Fig.
$\mathrm{S} 2 \mathrm{C}$ ), corresponding to a decrease in $\mathrm{N}_{2} \mathrm{O}$ concentra-

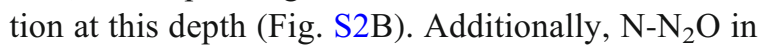
the chambers was enriched compared to the ambient $\mathrm{N}-\mathrm{N}_{2} \mathrm{O}$ at the end of the 60 min measurement period (Fig. S2C).

\section{Controls on nitrous oxide and methane fluxes}

In the 2012 growing season, the $\mathrm{N}_{2} \mathrm{O}$ fluxes from the pine and spruce sites correlated positively with soil $\mathrm{pH}$ and negatively with SOM content, soil water content, WFPS, water retention capacity (with 5-33 kPa pressure) and with fine sand/silt particles (Table 2). There was no correlation between $\mathrm{N}_{2} \mathrm{O}$ fluxes and precipitation. However, time lagged (three days) precipitation correlated negatively with the $\mathrm{N}_{2} \mathrm{O}$ flux (Table 2) and $\mathrm{NH}_{4}{ }^{+}$and $\mathrm{NO}_{3}{ }^{-}$content in soil (Table 2). The negative correlations were stronger in the A- than in the Ohorizon. Methane fluxes correlated positively with SOM content and water retention at $0.3 \mathrm{kPa}$ pressure in O-horizon, and negatively with electrical conductivity, $\mathrm{NH}_{4}{ }^{+}$concentrations, total porosity and water retention (with $0.3-1 \mathrm{kPa}$ ).

Principal component analysis revealed differences in the physical-chemical properties, such as particle size distribution, in soils of the pine and spruce sites (Fig. 4). Fine sand, silt and clay abundance in the spruce soil, a)

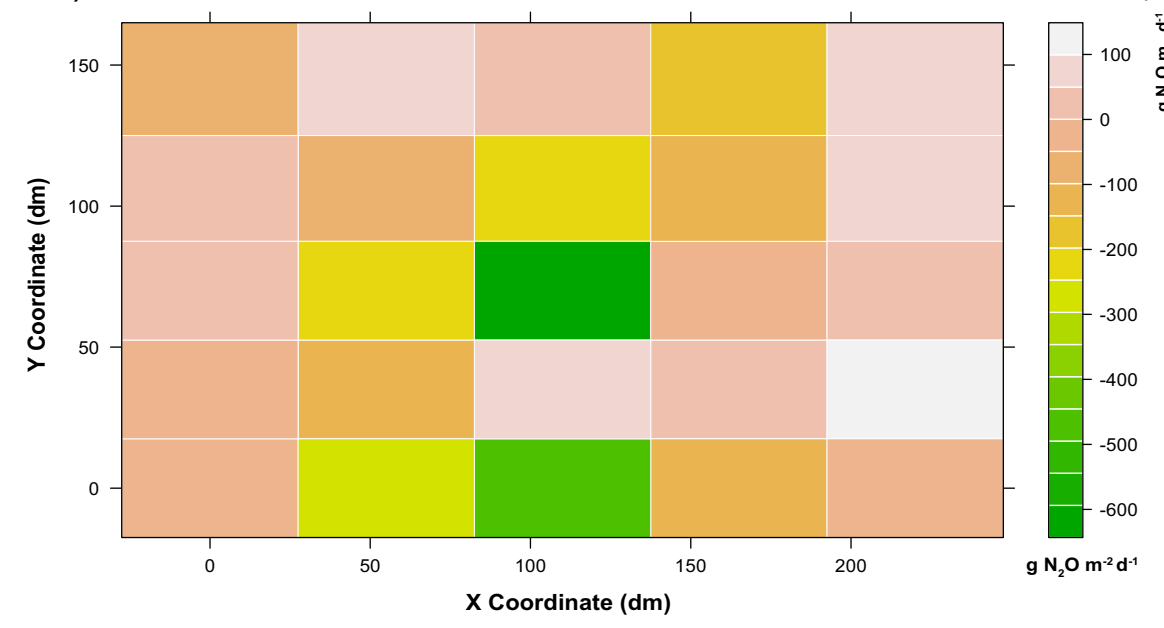

b)

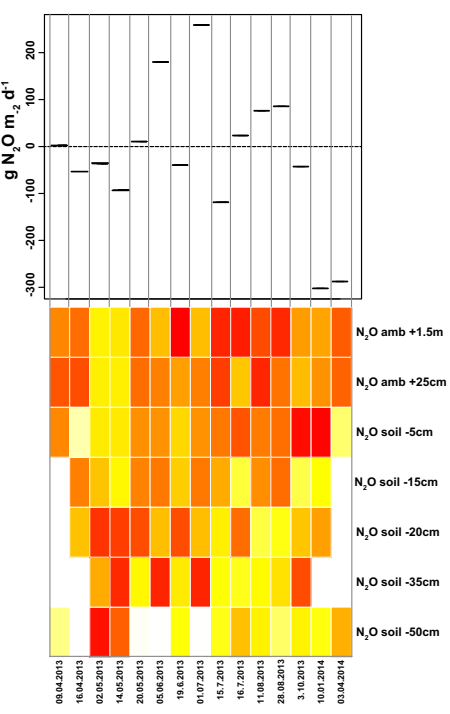

of same sampling points are plotted above. The color code is scaled to $\mathrm{N}_{2} \mathrm{O}$ concentrations of each sampling date, highest value of the day is presented with red and smallest with pale yellow (in printed with greyscale, highest value is black and smallest with pale gray). White cell presents "not analyzed" 
Table 2 Correlations between the background soil/environmental variables and the $\mathrm{N}_{2} \mathrm{O}$ and $\mathrm{CH}_{4}$ fluxes from pine and spruce sites in 2012. The correlations with soil variables were done either with the data from $\mathrm{O}$ - or A-horizons. $\mathrm{EC}=$ Electrical conductivity, LOI $=$ Loss of ignitition, SWC $=$ Soil water content, WFPS $=$

\begin{tabular}{|c|c|c|c|c|}
\hline $\begin{array}{l}\text { Spearman's correlation coefficiency } \\
\text { Data from } 2012 \text { three forest types together }\end{array}$ & $\begin{array}{l}\text { Spearman's rho } \\
\text { O-horizon } \\
\mathrm{N}_{2} \mathrm{O} \text { flux vs. }\end{array}$ & $\begin{array}{l}\text { Spearman's rho } \\
\text { A-horizon } \\
\mathrm{N}_{2} \mathrm{O} \text { flux vs. }\end{array}$ & $\begin{array}{l}\text { Spearman's rho } \\
\text { O-horizon } \\
\mathrm{CH}_{4} \text { flux vs. }\end{array}$ & $\begin{array}{l}\text { Spearman's rho } \\
\text { A-horizon } \\
\mathrm{CH}_{4} \text { flux vs. }\end{array}$ \\
\hline pH & $0.42 *$ & $0.303 \&$ & 0.130 & 0.186 \\
\hline EC & 0.061 & -0.005 & $-0.456 *$ & -0.294 \\
\hline LOI & 0.236 & $-0.307 \&$ & $0.369 \#$ & -0.19 \\
\hline $\mathrm{NH}_{4}^{+}$concentration & -0.181 & -0.003 & $-0.384 \#$ & $-0.408 *$ \\
\hline $\mathrm{NO}_{3}{ }^{-}$concentration & 0.218 & 0.010 & 0.211 & 0.096 \\
\hline Soil water content & -0.186 & $-0.433 *$ & -0.182 & -0.064 \\
\hline WFPS & -0.154 & $-0.424 *$ & -0.256 & -0.073 \\
\hline TP & 0.223 & 0.019 & 0.211 & $-0.452 *$ \\
\hline WC $0.3 \mathrm{kPa}$ & -0.019 & -0.135 & $0.512 *$ & $-0.383 \#$ \\
\hline WC 1 kPa & -0.186 & -0.236 & 0.115 & $-0.336 \&$ \\
\hline WC $5 \mathrm{kPa}$ & $-0.394 \#$ & $-0.303 \&$ & 0.0 & 0.062 \\
\hline WC $10 \mathrm{kPa}$ & $-0.355 \#$ & $-0.425 *$ & 0.088 & -0.274 \\
\hline WC 33 kPa & -0.297 & $-0.425 *$ & 0.114 & -0.274 \\
\hline WC $100 \mathrm{kPa}$ & -0.297 & -0.316 & 0.114 & -0.034 \\
\hline WC $1500 \mathrm{kPa}$ & -0.10 & 0.127 & 0.228 & -0.003 \\
\hline Coarse sand & NA & 0.306 & NA & 0.020 \\
\hline Medium sand & NA & 0.339 & NA & 0.060 \\
\hline Fine sand & NA & $-0.379 \#$ & NA & -0.180 \\
\hline Clay & NA & -0.200 & NA & -0.269 \\
\hline Silt sum & NA & $-0.314 \&$ & NA & -0.048 \\
\hline Sand sum & NA & 0.283 & NA & 0.110 \\
\hline Gravel sum & NA & -0.224 & NA & -0.208 \\
\hline Precipitation sum $24 \mathrm{~h}$ & & -0.11 & & 0.154 \\
\hline Precipitation sum $48 \mathrm{~h}$ & & -0.11 & & -0.002 \\
\hline Precipitation sum $72 \mathrm{~h}$ & & 0.160 & & 0.204 \\
\hline Time lagged precipitation $24 \mathrm{~h}$ after & & 0.105 & & 0.154 \\
\hline Time lagged precipitation 3 days after & & -0.239 & & -0.251 \\
\hline
\end{tabular}

Water filled pore space, $\mathrm{TP}=$ Total porosity, $\mathrm{VWC}=$ Volumetric water content at matrix potential e.g. $0.3 \mathrm{kPa}$. Significant correlations are bolded and shown with symbols ( $\&$ significant at $P<0.15$, \# significant at $P<0.10, *$ significant at $P<0.05$ ) 
Fig. 4 The association between the $\mathrm{N}_{2} \mathrm{O}$ fluxes and environmental factors/physical and chemical properties of A-horizon (year 2012, all sites) studied by principal component analysis (PCA). $\mathrm{EC}=$ Electrical conductivity, $\mathrm{LOI}=$ Loss of ignition, $\mathrm{SWC}=$ Soil water content, WFPS $=$ Water filled pore space, $\mathrm{WC} 33 \mathrm{kPa}=$ Soil water retention as volumetric water content at matrix potential at $33 \mathrm{kPa}$ pressure, $\mathrm{NH}_{4}{ }^{+}=$soil ammonium concentration, $\mathrm{NO}_{3}{ }^{-}=$soil nitrate concentration

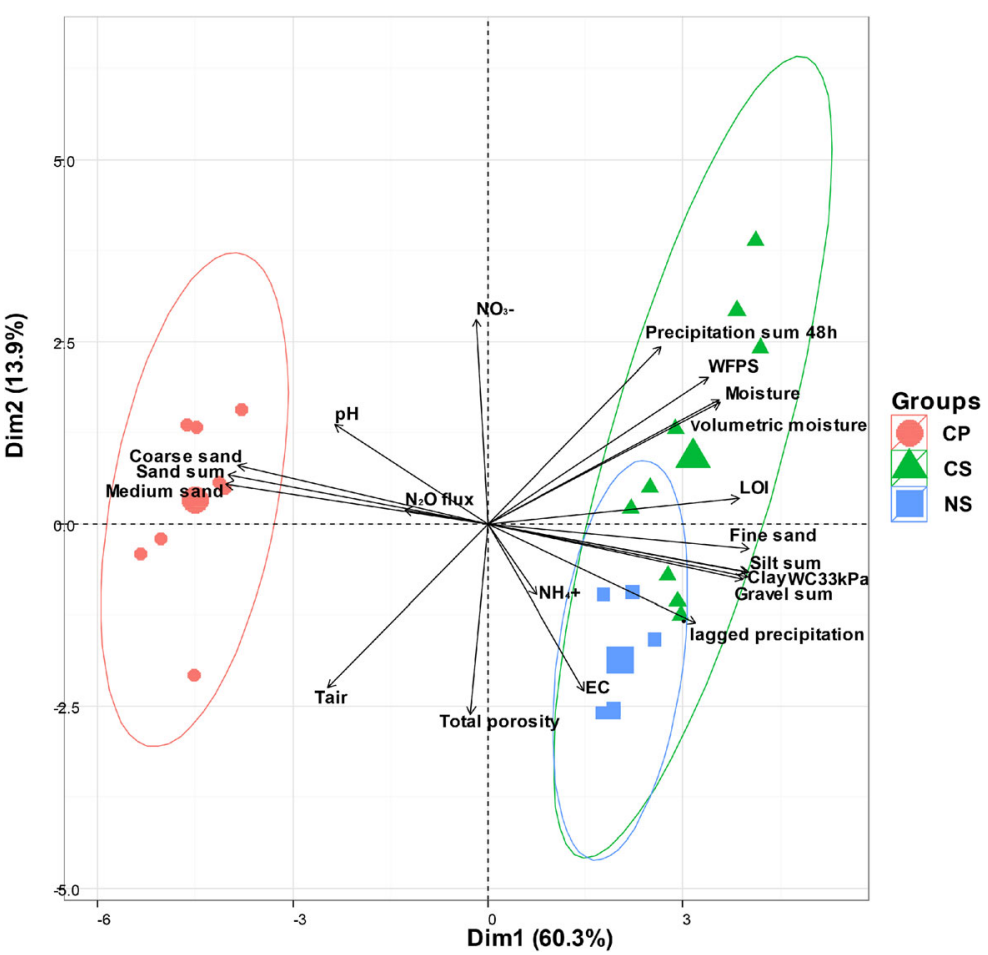

High WFPS reduces the $\mathrm{O}_{2}$ diffusion rates and can create $\mathrm{O}_{2}$ deficiency in soils. Our data demonstrates that $\mathrm{N}_{2} \mathrm{O}$ uptake took place primarily during winter and early spring when soil water content was high, there was the negative correlation between the $\mathrm{N}_{2} \mathrm{O}$ flux and the soil water content/water retention, suggesting that higher soil water content supports lower $\mathrm{N}_{2} \mathrm{O}$ fluxes. On the other hand, highest $\mathrm{CH}_{4}$ uptake rates were measured in summer when soil moisture was low and temperature high, promoting $\mathrm{CH}_{4}$ oxidation. High soil water content and the associated shortage of $\mathrm{O}_{2}$ is known to favor the reduction of $\mathrm{N}_{2} \mathrm{O}$ to $\mathrm{N}_{2}$ via denitrification (Davidson 1991; Miller et al. 2008). Our isotope results support the frequent occurrence of $\mathrm{N}_{2} \mathrm{O}$-to- $\mathrm{N}_{2}$ reduction in the spruce soils and thus $\mathrm{N}_{2} \mathrm{O}$ consumption. On the other hand, the highest $\mathrm{CH}_{4}$ uptake rates were measured in summer when soil moisture was low and temperature high. Nitrous oxide uptake peak periods have been reported in springtime in Australian savannahs, temperate pine and deciduous forest (Peichle et al. 2010; Livesley et al. 2011; Ullah and Moore 2011); periodic $\mathrm{N}_{2} \mathrm{O}$ uptake can thus be connected frequently to pulsing ground water tables (Mander et al. 2015). The maximum $\mathrm{N}_{2} \mathrm{O}$ uptake of $-631 \mu \mathrm{g} \mathrm{N} \mathrm{N}_{2} \mathrm{O}-\mathrm{N} \mathrm{m}^{-2} \mathrm{~d}^{-1}$ in our study occurred with high soil water content and is in the median range of reported $\mathrm{N}_{2} \mathrm{O}$ uptake fluxes for

Table 3 Linear mixed effect model results for $\mathrm{N}_{2} \mathrm{O}$ fluxes in pine and spruce forests on the growing season 2012 (equal sampling of P, CS and NS sites, dataset 1). Level of significance: ** significant at $P \leq 0.01, *$ significant at $P \leq 0.05, \times$ marginally significant at $P \leq 0.1$

\begin{tabular}{llllllll}
\hline & Estimate & Std. Error & t-value & $2.5 \%$ CI & $97.5 \%$ CI & $P$ value & Significance \\
\hline Fixed effects: & & & & & & & \\
(Intercept) & -96.83 & 345.92 & -0.28 & -760.97 & 571.19 & 0.789 & $* .011$ \\
Forest type & -132.39 & 47.55 & -2.78 & -230.45 & -37.66 & 0.383 \\
Soil layer & 34.03 & 38.31 & 0.89 & -42.90 & 107.41 & 0.550 & 0.074 \\
Treatment & 82.50 & 93.77 & 0.88 & -118.63 & 266.09 & 0.29 & 0.189 \\
Tair & -12.65 & 6.29 & -2.01 & -25.46 & -32.11 & 198.16 & \\
pH & 81.68 & 60.16 & 1.36 & & & \\
\hline
\end{tabular}


terrestrial ecosystems in general (Chapuis-Lardy et al. 2007). We can assume that denitrification was the key process for the $\mathrm{N}_{2} \mathrm{O}$ uptake since maximum uptake occurred when soil water content was high. Nitrous oxide concentration and the isotopic composition of $\mathrm{N}_{2} \mathrm{O}$ in soil profiles supported the conclusion that there was $\mathrm{N}_{2} \mathrm{O}$ reduction in the uppermost soil horizons. It is noteworthy that although low $\mathrm{pH}$ is known to limit $\mathrm{N}_{2} \mathrm{O}$ reductase $\left(\mathrm{N}_{2} \mathrm{OR}\right.$ activity) (Simek and Cooper 2002; Richardson et al. 2009; Liu et al. 2010; Bakken et al. 2012), the only known biological sink for $\mathrm{N}_{2} \mathrm{O}, \mathrm{N}_{2} \mathrm{O}$ reduction was high enough to allow $\mathrm{N}_{2} \mathrm{O}$ uptake in these acidic soils. These soils could therefore harbor acidtolerant denitrifiers as previously found in temperate and arctic wetlands (Palmer et al. 2010; Palmer et al. 2011).

The highest $\mathrm{N}_{2} \mathrm{O}$ uptake was measured during the low temperature periods, at the beginning and end of the growing season. However, the $\mathrm{N}_{2} \mathrm{O}$ uptake at low temperatures was likely a result of simultaneously high soil water content. It can be assumed that in summer when temperature is high but soil moisture is low, $\mathrm{N}_{2} \mathrm{O}$ emissions dominate over $\mathrm{N}_{2} \mathrm{O}$ uptake. In summer, the $\mathrm{N}_{2} \mathrm{O}$ producing processes are enhanced by elevated temperature (Butterbach-Bahl et al. 2013) so that reduction of $\mathrm{N}_{2} \mathrm{O}$ to $\mathrm{N}_{2}$ through denitrification cannot compensate for the overall $\mathrm{N}_{2} \mathrm{O}$ production. It has been reported that $\mathrm{N}_{2} \mathrm{O}$ emissions increase with temperature both in the field and laboratory studies (Dobbie and Smith 2001; Pärn et al. 2018). Here, the highest $\mathrm{N}_{2} \mathrm{O}$ emission in the spruce forests took place during July-August 2013 with high soil temperature and intermediate soil water content. The $\mathrm{N}_{2} \mathrm{O}$ concentration in the soil profile increased during summer in deeper soil layers, at times of the high $\mathrm{N}_{2} \mathrm{O}$ emissions. Enhanced soil organic matter decomposition and leaching of dissolved carbon to the deeper soil layers towards the end of the growing season are factors likely supporting $\mathrm{N}_{2} \mathrm{O}$ production and emissions (Voigt et al. 2017).

Although maximum $\mathrm{N}_{2} \mathrm{O}$ uptake occurred at high soil moisture, the CS site also showed periodic $\mathrm{N}_{2} \mathrm{O}$ uptake under dry summer conditions (Fig. 2). The ability of soils to consume $\mathrm{N}_{2} \mathrm{O}$ has been previously documented under drought conditions (Goldberg and Gebauer 2009) but poorly understood. The CS soil is characterized by a fine-grained soil structure (silty soil) which can, hypothetically, support the formation of anaerobic microsites even at low soil water content. A recent meta-analysis shows that intermediate soil water content can trigger highest $\mathrm{N}_{2} \mathrm{O}$ emissions, but very high soil moisture reduces $\mathrm{N}_{2} \mathrm{O}$ emissions and even allows $\mathrm{N}_{2} \mathrm{O}$ uptake (Pärn et al. 2018). Our results further support this finding and our linear models suggest that water retention is the strongest factor explaining the variation of $\mathrm{N}_{2} \mathrm{O}$ fluxes over the measurement period. Moreover, there was a significant negative correlation between soil water content (WFPS) and water retention values at higher pressure and fine soil texture. Although classical denitrification is an anaerobic process, some denitrifying bacteria can reduce $\mathrm{N}_{2} \mathrm{O}$ in aerobic conditions (Robertson et al. 1989, 1995; Chapuis-Lardy et al. 2007; Desloover et al. 2014; Qu et al. 2016).

We can expect that an increase in the availability of mineral $\mathrm{N}$ in soil resulting from $\mathrm{N}$ fertilization supports nitrification and denitrification activities, and finally $\mathrm{N}_{2} \mathrm{O}$ emissions. It is noteworthy that although the fertilized spruce site historically received a great amount of $\mathrm{N}$ in the past (in total $714 \mathrm{~kg} \mathrm{ha}^{-1}$ over 50 years), the content of $\mathrm{NO}_{3}{ }^{-}$and $\mathrm{NH}_{4}{ }^{+}$in the fertilized soil was higher but not significantly different during the study period from that in the non-fertilized soil (likely due to the fact that the last fertilization occurred already 34 years ago), showing that the effect of fertilization is short-lived (Saarsalmi and Mälkönen 2001). This indicates that this productive forest has capacity to store added $\mathrm{N}$ in the tree stand and within the soil. The additional $\mathrm{N}$ at the NS site increased organic matter content, $\% \mathrm{C}$ and $\% \mathrm{~N}$ in the organic horizons (Table 1). It has been shown that $\mathrm{N}$ fertilization increases the amount of organic matter in boreal coniferous forest soils (Martikainen 1996). However, even though there was no great difference in the mineral $\mathrm{N}$ content in the soils because the last fertilization occurred 3 years prior to this study, soil $\mathrm{pH}$ and $\mathrm{NH}_{4}{ }^{+}$content had a significant summary effect on the $\mathrm{N}_{2} \mathrm{O}$ fluxes in spruce sites (Table $\mathrm{S} 1$ ). Non-fertilized sub-site showed slightly higher capacity for $\mathrm{N}_{2} \mathrm{O}$ uptake $\left(-1.03 \mathrm{mg} \mathrm{N}_{2} \mathrm{O} \mathrm{m}{ }^{-2}\right.$ season $\left.^{-1}\right)$ than the fertilized sub-site $\left(-0.33 \mathrm{mg} \mathrm{N} \mathrm{N}_{2} \mathrm{O}\right.$ $\mathrm{m}^{-2}$ season ${ }^{-1}$ ). Higher $\mathrm{pH}$ in the fertilized spruce soil could explain this difference because soil $\mathrm{pH}$ correlated positively with the $\mathrm{N}_{2} \mathrm{O}$ fluxes in the studied acidic forest soils (Table 2).

The results from the pine forest stress the importance of soil structure on $\mathrm{N}_{2} \mathrm{O}$ fluxes. We could expect lower $\mathrm{N}_{2} \mathrm{O}$ emissions from pine forest soil than from spruce forest soil due to the lower $\mathrm{NO}_{3}{ }^{-}$content in pine forest soil. However, the pine site had higher $\mathrm{N}_{2} \mathrm{O}$ emissions indicating that the $\mathrm{N}_{2} \mathrm{O}$ reduction via denitrification in 
this coarse texture soil, in contrast to the fine texture spruce soil, was not strong enough to allow soil to act as a $\mathrm{N}_{2} \mathrm{O}$ sink. Winter can contribute significantly to the annual $\mathrm{N}_{2} \mathrm{O}$ emissions even though soil temperature is low (Maljanen et al. 2009). There are factors which favour the $\mathrm{N}_{2} \mathrm{O}$ production in frozen soil (Koponen et al. 2004, 2006). However, the spruce soil here demonstrated $\mathrm{N}_{2} \mathrm{O}$ uptake during winter likely resulted from low soil $\mathrm{NO}_{3}{ }^{-}$content (low $\mathrm{N}$ mineralization at cold temperatures) during the dormant seasons. Furthermore, low $\mathrm{O}_{2}$ availability in the soil resulting from high soil moisture during the dormant seasons favour the reduction of $\mathrm{N}_{2} \mathrm{O}$.

In this study, the correlation between soil $\mathrm{N}_{2} \mathrm{O}$ concentrations and flux rates was weak but present. Nevertheless, the $\mathrm{N}_{2} \mathrm{O}$ concentrations in the soil profiles provided information about the fate of $\mathrm{N}_{2} \mathrm{O}$ in soil. In general, the $\mathrm{O}$ and $\mathrm{A}$ soil horizons $(-5$ and $-15 \mathrm{~cm}$ soil layer) of the $\mathrm{CS}$ site had lower $\mathrm{N}_{2} \mathrm{O}$ concentrations than the deeper layers and displayed below atmospheric concentrations when the site showed $\mathrm{N}_{2} \mathrm{O}$ uptake, suggesting that the uppermost soil layers were potential sinks for atmospheric $\mathrm{N}_{2} \mathrm{O}$. The ${ }^{15} \mathrm{~N}$ enrichment in $\mathrm{N}_{2} \mathrm{O}$ in the uppermost soil horizon and in the emitted $\mathrm{N}_{2} \mathrm{O}$ in the spruce forest indicates that discrimination against the heavier isotope of $\mathrm{N}_{2} \mathrm{O}-\mathrm{N}$ has occurred during the microbial processes, likely during $\mathrm{N}_{2} \mathrm{O}$ reduction. ${ }^{15} \mathrm{~N}$ enrichment in the $\mathrm{N}_{2} \mathrm{O}$ towards uppermost soil horizons has been reported previously (Goldberg and Gebauer 2009; Gil et al. 2017).

Our results show that in addition to $\mathrm{CH}_{4}$ uptake $\mathrm{N}_{2} \mathrm{O}$ uptake must also be considered when evaluating the atmospheric impact of the trace greenhouse gases $\left(\mathrm{CH}_{4}\right.$ and $\left.\mathrm{N}_{2} \mathrm{O}\right)$ in boreal coniferous forests. Here, the GWP of $\mathrm{N}_{2} \mathrm{O}$ uptake in the growing season 2013 (April 9th - October 3rd) of the control spruce site (CS) (mean -1396 , s.e. $1618 \mathrm{mg} \mathrm{CO}_{2}$-eq season ${ }^{-1} \mathrm{~m}^{-2}$ ), was about $35 \%$ of the GWP of the $\mathrm{CH}_{4}$ uptake (mean -4629 , s.e. $1955 \mathrm{mg} \mathrm{CO}$-eq season ${ }^{-1} \mathrm{~m}^{-2}$ ). In a Mediterranean pine forest even higher periodic contribution of $\mathrm{N}_{2} \mathrm{O}$ uptake has been reported, $60 \%$ of the GWP of $\mathrm{CH}_{4}$, however these measurements were done in a shorter time period, only over springtime (Rosenkranz et al. 2006). We provide here a first approximation of the seasonal $\mathrm{N}_{2} \mathrm{O}$ budget for boreal spruce forest soils, possibly be biased by relatively low sampling frequency. However, a good spatial coverage of fluxes were included and simultaneous $\mathrm{CH}_{4}$ budget was as expected (Saari 2003; Dutaur and Verchot 2007; Kirschke et al.
2013; Yu et al. 2017)., The measurements covered the peak emission/uptake periods and the data allow us to compare $\mathrm{N}_{2} \mathrm{O}$ flux to $\mathrm{CH}_{4}$ flux, which was a main aim of this study.

Methane oxidation and $\mathrm{CH}_{4}$ uptake can be lowered by $\mathrm{NH}_{4}{ }^{+}$addition in boreal forest soil (Saari et al. 2004) but there are also contrasting results about the effects of $\mathrm{NH}_{4}{ }^{+}$in forest soils (Börjersson and Nohrsted 1998). According to the results reported here even the addition of a large amount of $\mathrm{N}$ in $\mathrm{N}$-limited coniferous boreal forest ecosystem does not obviously cause drastic longterm changes in the $\mathrm{CH}_{4}$ (no statistical difference between the CS and NS sites) (Fig. 1) and $\mathrm{N}_{2} \mathrm{O}$ dynamics after the ecosystem has immobilized the added $\mathrm{N}$.

Based on our observations, there are basic differences in the $\mathrm{N}_{2} \mathrm{O}$ dynamics in various boreal forests, some having even negative annual $\mathrm{N}_{2} \mathrm{O}$ balance, i.e. uptake. Therefore, the evaluation of the total $\mathrm{N}_{2} \mathrm{O}$ balance and atmospheric impact of boreal forests requires more $\mathrm{N}_{2} \mathrm{O}$ data from forests with different soil characteristics. Only after that, the accurate upscaling of the $\mathrm{N}_{2} \mathrm{O}$ fluxes over the whole boreal region, and evaluation of the relevance of $\mathrm{N}_{2} \mathrm{O}$ uptake by these ecosystems, will be possible.

\section{Conclusions}

This study shows that the capacity of boreal coniferous forests to act as sinks for atmospheric $\mathrm{N}_{2} \mathrm{O}$ largely depends on their soil structure and soil water content. Spruce forests with finer soil structure showed higher $\mathrm{N}_{2} \mathrm{O}$ uptake than pine forest soils with coarser soil structure. The $\mathrm{N}_{2} \mathrm{O}$ uptake by boreal coniferous forest soils can contribute substantially to the total atmospheric impact of the trace greenhouse gas $\left(\mathrm{CH}_{4}+\mathrm{N}_{2} \mathrm{O}\right)$ fluxes in these ecosystems.

Acknowledgements We thank Hanne Vainikainen, Sanjeeb Saha and Simo Jokinen for technical assistance. This work was supported by the Academy of Finland [290315 and 258875]. We thank Dr. Aino Smolander for providing access and the history to the Heinävei spruce site.

Funding Information Open access funding provided by University of Eastern Finland (UEF) including Kuopio University Hospital.

Open Access This article is licensed under a Creative Commons Attribution 4.0 International License, which permits use, sharing, adaptation, distribution and reproduction in any medium or format, as long as you give appropriate credit to the original author(s) and 
the source, provide a link to the Creative Commons licence, and indicate if changes were made. The images or other third party material in this article are included in the article's Creative Commons licence, unless indicated otherwise in a credit line to the material. If material is not included in the article's Creative Commons licence and your intended use is not permitted by statutory regulation or exceeds the permitted use, you will need to obtain permission directly from the copyright holder. To view a copy of this licence, visit http://creativecommons.org/licenses/by/4.0/.

\section{References}

Ambus P, Robertson GP (2006) The effect of increased N deposition of nitrous oxide, methane and carbon dioxide fluxes from unmanaged forest and grassland communities in Michigan. Biogeochem 79:315-337

Arah J, Smith I, Crighton I, Li HS (1991) Nitrous oxide production and denitrification 438 in Scottish arable soils. J Soil Sci 42: 351-367

Archibold OW (1995) Ecology of world vegetation. Chapman and Hall, London, pp 1-510

Bakken LR, Bergaust L, Liu B, Frostegåd Å (2012) Regulation of denitrification at that cellular level: a clue to the understanding of $\mathrm{N}_{2} \mathrm{O}$ emissions from soils. Philos Trans R Soc Lond B 367:1226-1234

Bates D, Mächler M, Bolker B, Walker S (2015). "Fitting Linear Mixed-Effects Models Using lme4." Journal of Statistical Software, 67(1), 1-48. https://doi.org/10.18637/jss.v067.i01

Blasing TJ (2017) Recent greenhouse gas concentrations. https://doi.org/10.3334/CDIAC/atg.032

Börjersson B, Nohrsted HO (1998) Short- and long-term effects of nitrogen fertilization on methane oxidation in three Swedish forest soils. Biol Fertil Soils 27:113-118

Bowden RD, Steudler PA, Melillo JM (1990) Annual nitrous oxide fluxes from temperate forest soils in the northeastern United States. J Geophys Res 95:13997-14005

Bowden RD, Melillo JM, Steudler PA, Aber JD (1991) Effects of nitrogen additions on annual nitrous oxide fluxes from temperate forest soils in the northeastern United States. J Geophys Res 8:9321-9328

Braker G, Conrad R (2011) Diversity, structure, and size of $\mathrm{N}_{2} \mathrm{O}$ producing microbial communities in soils - what matters for their functioning? Adv Appl Microbiol 75:33-70

Brumme R, Verchot LV, Martikainen PJ, Potter CS (2005) Contribution of trace gases nitrous oxide $\left(\mathrm{N}_{2} \mathrm{O}\right)$ and methane $\left(\mathrm{CH}_{4}\right)$ to the atmospheric warming balance of forest biomes. In: Griffiths H, Jarvis PJ (eds) The Carbon Balance of Forest Biomes. Taylor \& Francis Group, New York, pp 293-318

Brummell ME, Farrell, RE, Hardy SP, Siciliano SD (2014) Greenhouse gas production and consumption in High Arctic deserts. Soil Biology and Biochemistry 68:158-165

Butterbach-Bahl K, Gasche R, Huber C, Kreutzer K, Papen H (1998) Impact of $\mathrm{N}$-input by wet deposition on $\mathrm{N}$-trace gas fluxes and $\mathrm{CH}_{4}$-oxidation in spruce forest ecosystems of the temperate zone in Europe. Atmos Environ 32:559-564

Butterbach-Bahl K, Breuer L, Gasche R, Willibald G, Papen H (2002) Exchange of trace gases between soils and the atmosphere in scots pine forest ecosystems of the northeastern German lowlands: 1 . Fluxes of $\mathrm{N}_{2} \mathrm{O}, \mathrm{NO} / \mathrm{NO}_{2}$ and $\mathrm{CH}_{4}$ at forest sites with different N-deposition. For Ecol Manag 167: 123-134

Butterbach-Bahl K, Baggs EM, Dannenmann M, Kiese R, Zechmeister-Boltenstern S (2013) Nitrous oxide emissions from soils: how well do we understand the processes and their controls? Phil Trans R Soc B 368:20130122

Chapuis-Lardy L, Wrage N, Metay A, Chotte JL, Bernoux M (2007) Soils, a sink for $\mathrm{N}_{2} \mathrm{O}$ ? A review. Glob Change Biol 13:1-17

Davidson EA (1991) Fluxes of $\mathrm{N}_{2} \mathrm{O}$ from terrestrial ecosystems. In: Rogers JE, Whitmaneds WB (eds) Microbial production and consumption of greenhouse gases, Methane, Nitrous oxides and Halomethanes. American Society for Microbiology, Washington DC, pp 219-235

Desloover J, Roobroeck D, Heylen K, Puig S, Boeckx P, Verstraete W, Boon N (2014) Pathway of nitrous oxide consumption in isolated Pseudomonas stutzeri strains under anoxic and oxic conditions. Env Microb 16:3142-3152. https://doi.org/10.1111/1462-2920.12404

Dobbie KE, Smith KA (2001) The effects of temperature, water filled pore space and land use on $\mathrm{N}_{2} \mathrm{O}$ emissions from an imperfectly drained gleysol. Eur J Soil Sci 52:667-673

Dong Y, Scharffe D, Lobert JM, Crutzen PJ, Sanhueza E (1998) Fluxes of $\mathrm{CO}_{2}, \mathrm{CH}_{4}$ and $\mathrm{NO}$ from a temperate forest soil: the effects of leaves and humus layers. Tellus Ser B Chem Phys Meteorol 50:243-252

Dutaur L, Verchot LV (2007) A global inventory of the soil $\mathrm{CH}_{4}$ sink. Glob Biogeochem Cycl 21:GB4013

Fawcett JK, Scott JE (1960) A rapid and precise method for the determination of urea. J Clin Pathol 13:156-159

Flückiger J, Dällenbach A, Blunier T, Stauffer B, Stocker TF et al (1999) Variations in atmospheric $\mathrm{N}_{2} \mathrm{O}$ concentration during abrupt climatic changes. Science 285:227-230

Forster P, Ramaswamy V, Artaxo P, Berntsen T, Betts R et al. (2007) Changes in atmospheric constituents and in radiative forcing. In: Climate Change 2007: The physical science basis. Contribution of Working Group I to the Fourth Assessment Report of the Intergovernmental Panel on Climate Change. Cambridge University Press, Cambridge, United Kingdom and New York, NY, USA

Gil J, Pérez T, Boering K, Martikainen PJ, Biasi C (2017) Mechanisms responsible for high $\mathrm{N} 2 \mathrm{O}$ emissions from subarctic permafrost peatlands studied via stable isotope techniques. Glob Biogeochem Cycles 31:172-189. https://doi. org/10.1002/2015GB005370

Goldberg SD, Gebauer G (2009) Drought turns a central European Norway spruce forest soil from an $\mathrm{N}_{2} \mathrm{O}$ source to a transient $\mathrm{N}_{2} \mathrm{O}$ sink. Glob Change Biol 15:850-860

Goossens A, De Visscher A, Boeckx P et al (2001) Two-year field study on the emission of $\mathrm{N}_{2} \mathrm{O}$ from coarse and middletextured Belgian soils with different land use. Nutr Cycl Agroecos 60:23-34

Groffman PM, Tiedje JM, Robertson GP, Christensen S (1988) Denitrification at different temporal and geographical scales: proximal and distal controls. In: Wilson JR (ed) Advances in nitrogen cycling in agricultural ecosystems. CAB International, Wallingford, U.K., pp 174-192 
Heiskanen J (1993) Variation in water retention characteristics of peat growth media used in tree nurseries. Silva Fenn 27:7797. https://doi.org/10.14214/sf.a15664

Hofmann DJ, Butler JH, Dlugokencky EJ, Elkins JW, Masarie K, Montzka SA, Tans P (2006) The role of carbon dioxide in climate forcing from 1979 to 2004: introduction of the annual greenhouse gas index. Tellus 58:614-619

IUSS Working Group WRB. (2006) World reference base for soil resources 2006. World soil resources reports no. 103. FAO, Rome

Kanakidou M, Myriokefalitakis S, Daskalakisa N, Fanourgakis G (2016) Past, present, and future atmospheric nitrogen deposition. J Atmos Sci 73:2039-2047

Kassambara A and Mundt F (2016) Factoextra: extract and visualize the results of multivariate data analyses. $\mathrm{R}$ package version 1.0.3. http://CRAN.R-project.org/package= factoextra

Kirschke S, Bousquet P, Ciais P, Saunois M, Canadell JG, Dlugokencky EJ, Bergamaschi P, Bergmann D, Blake DR, Bruhwiler L, Cameron-Smith P, Castaldi S, Chevallier F, Feng L, Fraser A, Heimann M, Hodson EL, Houweling S, Josse B, Fraser PJ, Krummel PB, Lamarque JF, Langenfelds RL, le Quéré C, Naik V, O'Doherty S, Palmer PI, Pison I, Plummer D, Poulter B, Prinn RG, Rigby M, Ringeval B, Santini M, Schmidt M, Shindell DT, Simpson IJ, Spahni R, Steele LP, Strode SA, Sudo K, Szopa S, van der Werf GR, Voulgarakis A, van Weele M, Weiss RF, Williams JE, Zeng G (2013) Three decades of global methane sources and sinks. Nat Geosci 6:813-823

Klemedtsson L, Klemedtsson AK, Moldan F (1997) Nitrous oxide emission from Swedish forest soils in relation to liming and simulated increased N-deposition. Biol Fertil Soils 25:290295

Klute A (1986) Methods of soil analysis. Part 1. Physical and mineralogical methods, 2nd ed. agronomy monograph 9. American Society of Agronomy and Academic Press: Madison, WI, USA

Kool DM, Dolfing J, Wrage N, Van Groenigen JW (2011) Nitrifier denitrification as a distinct and significant source of nitrous oxide from soil. Soil Biol Biochem 43:174-178

Koponen HT, Flöjt L, Martikainen PJ (2004) Nitrous oxide emissions from agricultural soils at low temperatures: a laboratory microcosm study. Soil Biol Biochem 36:757-766

Koponen HT, Escude Duran C, Maljanen M, Hytönen J, Martikainen PJ (2006) Temperature responses of NO and $\mathrm{N}_{2} \mathrm{O}$ emissions from boreal organic soil. Soil Biol Biochem 38:1779-1787

Kowalchuk GA, Stephen JR (2001) Ammonia-oxidizing bacteria: a model for molecular biology. Annu Rev Microbiol 55:485529. https://doi.org/10.1146/annurev.micro.55.1.485

Laughlin RJ, Stevens RJ (2002) Evidence for fungal dominance of denitrification and codenitrification in a grassland soil. Soil Sci Soc Am J 66:1540-1548

Lê S, Josse J, Husson F (2008) FactoMineR: an R package for multivariate analysis. J Stat Softw 25:1-18

Liu XR, Dong YS, Qi YC, Li SG (2010) $\mathrm{N}_{2} \mathrm{O}$ fluxes from the native and grazed semi-arid steppes and their driving factors in Inner Mongolia, China. Nutr Cycl Agroecosys 86:231240

Livesley SJ, Grover S, Hutley LB, Jamali H, Butterbach-Bahl K, Fest B, Beeinger J, Arndt SK (2011) Seasonla variation and fire effects on $\mathrm{CH}_{4}, \mathrm{~N}_{2} \mathrm{O}$, and $\mathrm{CO}_{2}$ exchange in savanna soils of northers Australia. Agric For Meteorol 151:1440-1452

MacFarling Meure C, Etheridge D, Trudinger C, Steele P, Langenfelds R, van Ommen T, Smith A, Elkins J (2006) Law dome $\mathrm{CO}_{2}, \mathrm{CH}_{4}$ and $\mathrm{N}_{2} \mathrm{O}$ ice core records extended to 2000 years BP. Geophys Res Lett 33:L14810

Machakova K, Vainio E, Urban O, Pihlatie M (2019) Seasonal dynamics of stem $\mathrm{N} 2 \mathrm{O}$ exhange follow the physiological activity of boreal trees. Nat Commun 10:4989

Machida T, Nakazawa T, Fujii Y, Aoki S, Watanabe O (1995) Increase in the atmospheric nitrous oxide concentration during the last 250 years. Geophys Res Lett 22:2921-2924

Maljanen M, Virkajärvi P, Hytönen J, Öquist M, Sparrman T, Martikainen PJ (2009) Nitrous oxide production in boreal soils with variable organic matter content at low temperature - snow manipulation experiment. Biogeosciences 6:24612473

Mander Ü, Maddison M, Soosaar K, Teemusk A, Kanal A, Uri V, Truu J (2015) The impact of a pulsing groundwater table on greenhouse gas emissions in riparian grey alder stands. Environ Sci Pollut Res Int 22:2360-2371. https://doi. org/10.1007/s11356-014-3427-1

Martikainen PJ (1984) Nitrification in two coniferous forest soils after different fertilization treatments. Soil Biol Biochem 16: 577-582

Martikainen PJ (1996). Microbial processes in boreal forest soils as affected by forest management practices and atmospheric stress. Soil biochemistry, 9:195-222. Ed by. G. Stotzky and J.M. Bollag. Marcell Dekker, Inc., New York

Martikainen PJ, Nykänen H, Crill P, Silvola J (1993) Effect of a lowered water table on nitrous oxide fluxes from northern peatlands. Nature 366:51-53

Marushchak ME, Pitkämäki A, Koponen H, Biasi C, Seppälä M, Martikainen PJ (2011) Hot spots for nitrous oxide emissions found in different types of permafrost peatlands. Glob Chang Biol 17:2601-2614

Megonigal JP, Hines ME, Visscher PT. 2004. Anaerobic metabolism: linkages to trace gases and aerobic processes. Pp. 317424 in biogeochemistry, W.H. Schlesinger (editor). ElsevierPergamon: Oxford, U.K.

Miller MN, Zebarth BJ, Dandie CE, Burton DL, Goyer C, Trevors JT (2008) Crop residue influence on denitrification, $\mathrm{N}_{2} \mathrm{O}$ emissions and denitrifier community abundance in soil. Soil Biol Biochem 40:2553-2562

Miranda KM, Espey MG, Wink DA (2001) A rapid simple spectrophotometric method for simultaneous detection of $\mathrm{NO}_{2}{ }^{-}$and $\mathrm{NO}_{3}{ }^{-}$. Nitric Oxide 5:62-71

Myhre GD, Shindell FM, Bréon W, Collins J, Fuglestvedt J, Huang J et al. (2013) "Anthropogenic and natural radiative forcing," in Climate Change 2013: The Physical Science Basis. Contribution of Working Group I to the Fifth Assessment Report of the Intergovernmental Panel on Climate Change, eds T. F. Stocker, D. Qin, G.-K. Plattner, M. Tignor, S. K. Allen, J. Boschung, et al. (Cambridge: Cambridge University Press)

Myhre G, Shindell D, Pongratz J (2014) Anthropogenic and Natural Radiative Forcing. In: Stocker, Thomas (ed.) Climate change 2013: the physical science basis; Working Group I contribution to the fifth assessment report of the Intergovernmental Panel on Climate Change. Cambridge: Cambridge University Press. pp. 659-740 
Nykänen H, Alm J, Lang K, Silvola J, Martikainen PJ (1995) Emissions of $\mathrm{CH}_{4}, \mathrm{~N}_{2} \mathrm{O}$ and $\mathrm{CO}_{2}$ from a Virgil fen and a fen drained for grassland in Finland. J Biogeogr 22:351-357

Palmer K, Drake HL, Horn MA (2010) Association of novel and highly diverse acid-tolerant denitrifiers with $\mathrm{N}_{2} \mathrm{O}$ fluxes of an acidic fen. Appl Environ Microbiol 76:1125-1134

Palmer K, Biasi C, Horn MA (2011) Contrasting denitrifier communities relate to contrasting $\mathrm{N}_{2} \mathrm{O}$ emission patterns from acidic peat soils in arctic tundra. ISME J 6:1058-1077

Pärn J, Verhoeva JTA, Butterbach-Bahl K, Dise NB, Ullah S, Aasa A, Egorov S, Espenber M, Järveoja J, Jauhiainen J, Kasak K, Klemedtsson L, Kull A, Laggoun-Défarge F, Lapshina ED, Lohila A, Lõhmus K, Maddison M, Mitsch WJ, Müller C, Niinimets Ü, Osborne B, Pae T, Salm JO, Sgouridis F, Sohar K, Soosaar K, Storey K, Teemusk A, Tenywa MM, Tournebize J, Truu J, Veber G, Villa JA, Sann Zaw S, Mander Ü (2018) Nitrogen-rich organic soils under warm well- drained conditions are global nitrous oxide emission hotspots. Nat Commun 9:1135. https://doi. org/10.1038/s41467-018-03540-1

Paulo J, Ribeiro J, Diggle PJ (2016) geoR: analysis of Geostatistical data. R package version 1:7-5.2 https://CRAN.R-project.org/package=geoR

Peichle M, Arian MA, Ullah S, Moore TR (2010) Forest floor carbon dioxide, methane and nitrous oxide exchanges in an age-sequence of eastern white pine forests. Glob Chang Biol 16:2198-2212

Pihlatie M, Pumpanen J, Rinne J, Ilvesniemi H, Simojoki A, Hari P, Vesala T (2007) Gas concentration driven fluxes of nitrous oxide and carbon dioxide in boreal forest soil. Tellus Ser B Chem Phys Meteorol 59:458-469

Priha O, Smolander A (1999) Nitrogen transformations in soil under Pinus sylvestris, Picea abies and Betula pendula at two forest sites. Soil Biol Biochem 31:965-977

Priha O, Grayston SJ, Pennanen T, Smolander A (1999) Microbial activity related to $\mathrm{C}$ and $\mathrm{N}$ cycling and microbial community structure in the rhizospheres of Pinus sylvestris, Picea abies and Betula pendula seedlings in an organic and mineral soil. FEMS Microbial Ecol 30:187-199

Qu Z, Bakken LR, Molstad L, Frostegård Å, Bergaust LL (2016) Transcriptional and metabolic regulation of denitrification in Paracoccus denitrificans allows low but significant activity of nitrous oxide reductase under oxic conditions. Env Microbiol 18:2951-2963

R Core Team (2015) R: a language and environment for statistical computing. R Foundation for Statistical Computing

Richardson D, Felgate H, Watmough N, Thomson A, Baggs E (2009) Mitigating release of the potent greenhouse gas $\mathrm{N}_{2} \mathrm{O}$ from the nitrogen cycle-could enzymic regulation hold the key? Trends Biotechnol 27:388-397

Robertson GP (1989) Nitrification and denitrification in humid tropical systems. Eds. J. Proctor. In: Mineral nutrients in tropical forest and savanna ecosystems. Blackwell Scientific, Campbridge, Massachusetts, USA, pp 55-69

Robertson LA, Dalsgaard T, Revsbech NP, Kuenen JG (1995) Confirmation of 'aerobic denitrification' in batch cultures, using gas chromatography and ${ }^{15} \mathrm{~N}$ mass spectrometry. FEMS Microbiol Ecol 18:113-119

Rosenkranz P, Brüggemann N, Papen H, Xu Z, Seufert G, Butterbach-Bahl K (2006) $\mathrm{N}_{2} \mathrm{O}$, NO and $\mathrm{CH}_{4}$ exchange, and microbial $\mathrm{N}$ turnover over a Mediterranean pine forest soil. Biogeosciences 3:121-133

Ryden JC (1981) $\mathrm{N}_{2} \mathrm{O}$ exchange between a grassland soil and the atmosphere. Nature 292:235-237

Saari A (2003) Methane oxidation in forest soils as affected by environmental changes. Doctoral Dissertation. Kuopio University Publications C. Natural and Environmental Sciences. Kuopio, Finland. ISBN: 951-781-258-2

Saari A, Rinnan R, Martikainen PJ (2004) Methane oxidation in boreal forest soils: kinetics and sensitivity to $\mathrm{pH}$ and ammonium. Soil Biol Biochem 36:1037-1046

Saarsalmi A, Mälkönen (2001) Forest fertilization research in Finland: a literature review. Scand J For Res 16:514 416

Saarsalmi A, Tamminen P, Kukkola M (2014) Effects of longterm fertilisation on soil properties in scots pine and Norway spruce stands. Silva Fennica 48

Schlesinger WH (2013) An estimate of the global sink for nitrous oxide in soils. Glob Change Biol 19:2929-2931

Schneider Y, Beier M, Rosenwinkel K (2012) Effect of substrate availability on nitrous oxide production by deammonification processes under anoxic conditions. Microb Biotechnol 5: 415-424

Shrestha NK, Hadano S, Kamachi T, Okura I (2002) Dinitrogen production from ammonia by Nitrosomonas europaea. Appl Catal A Gen 237:33-39

Shvaleva A, Siljanen HMP, Correia A, Costa e Silva F, Lamprecht RE, Lobo-do-Vale R, Bicho C, Fangueiro D, Anderson M, Pereira JS, Chaves MM, Cruz C, Martikainen PJ (2015) Environmental and microbial factors influencing methane and nitrous oxide fluxes in Mediterranean cork oak woodlands: trees make a difference. Front Microbiol 6:1104. https://doi.org/10.3389/fmicb.2015.01104

Simek M, Cooper JE (2002) The influence of soil pH on denitrification: progress towards the understanding of this interaction over the last 50 years. Eur J Soil Sci 53:345-354

Spott O, Russow R, Stange FC (2011) Formation of hybrid $\mathrm{N}_{2} \mathrm{O}$ and hybrid $\mathrm{N}_{2}$ due to codenitrification: first review of a barely considered process of microbially mediated N-nitrosation. Soil Biol Biochem 43:1995-2011

Stewart KJ, Brummell ME Farrell RE Siciliano SD (2012) N2O flux from plant-soil systems in polar deserts switch between sources and sinks under different light conditions. Soil Biol Biochem 48:69-77

Syakila A, Carolien K (2011) The global nitrous oxide budget revisited. Greenhouse Gas Measurement and Management 1: 17-26. https://doi.org/10.3763/ghgmm.2010.0007

Tate RL (1995) Soil microbiology. John Wiley, New York, NY

Thomas KL, Lloyd D, Boddy L (1994) Effects of oxygen, pH and nitrate concentration on denitrification by Pseudomonas species. FEMS Microb Lett 118:181-186

Thomson AJ, Giannopoulos G, Pretty J, Baggs EM, Richardson DJ (2012) Biological sources and sinks of nitrous oxide and strategies to mitigate emissions. Phil Trans R Soc B 367: $1157-1168$

Tiedje JM (1987) Ecology of denitrification and dissimilatory nitrate reduction to ammonium. In: Zehnder AB (ed) Environmental microbiology of anaerobes•. John Wiley \& Sons, New York, pp 179-244

Turkington R, John E, Krebs CJ, Dale MRT, Nams VO, Boonstra R, Boutin S, Martin K, Sinclair ARE, Smith JNM (1998) The 
effects of NPK fertilization for nine years on boreal forest vegetation in northwestern Canada. J Veg Sci 9:333-346

Ullah S, Moore TR (2011) Biogeochemical controls on methane, nitrous oxide, and carbon dioxide fluxes from deciduous forest soils in eastern Canada. J Geophys Res 116:G03010

Van Cleemput O, Samater AH (1995) Nitrite in soils: accumulation and role in the formation of gaseous $\mathrm{N}$ compounds. Fertil Res 45:81-89

Vieten B, Blunier T, Neftel A, Alewell C, Conen F (2007) Fractionation factors for stable isotopes of $\mathrm{N}$ and $\mathrm{O}$ during $\mathrm{N}_{2} \mathrm{O}$ reduction in soil depend on reaction rate constant. Rapid Common Mass Spectrom 21:846-850

Voigt C, Lamprecht RE, Marushchak ME, Lind SE, Novakovsky A, Aurela M, Martikainen PJ, Biasi C (2017) Warming of subarctic tundra increases emissions of all three important greenhouse gases - carbon dioxide, methane, and nitrous oxide. Glob Change Biol 23:3121-3138

Wallenstein MD, Myrold DD, Firestone M, Voytek M (2006) Environmental controls on denitrifying communities and denitrification rates: insughts from molecular methods. Ecol Appl 16:2143-2152

Weier KL, Doran JW, Power JF, Walters DT (1993) Denitrification and the dinitrogen/nitrous oxide ratio as affected by soil water, available carbon, and nitrate. Soil Sci Soc Am J 57:66-72

Wrage N, van Groenigen JW, Oenema O, Baggs EM (2005) A novel dual-isotope labeling method for distinguishing between soil sources of $\mathrm{N}_{2} \mathrm{O}$. Rapid Commun Mass Spectrom 19:3298-3306. https://doi.org/10.1002/rcm.2191

Yu L, Huang Y, Zhang W, Li T, Sun W (2017) Methane uptake in global forest and grassland soils from 1981 to 2010. Sci Total Environ 607-608:1163-1172

Zart D, Bock E (1998) High rate of aerobic nitrification and denitrification by Nitrosomonas eutropha grown in a fermentor with complete biomass retention in the presence of gaseous $\mathrm{NO}_{2}$ or NO. Arch Microbiol 169:282-286

Zhang J, Müller C, Cai Z (2015) Heterotrophic nitrification of organic $\mathrm{N}$ and its contribution to nitrous oxide emissions in soils. Soil Biol Biochem 84:199-209

Zuur A, Ieno E, Walker N, Saveliev A, Smith G (2009) Mixed effects models and extensions in ecology with R. Spriunger, New York, p 574

Publisher's note Springer Nature remains neutral with regard to jurisdictional claims in published maps and institutional affiliations. 